BUSINESS GROUP AFFILIATION, PERFORMANCE, CONTEXT, AND STRATEGY:

A META-ANALYSIS*

Final version: $\underline{\text { http://amj.aom.org/content/54/3/437.short }}$

\author{
Michael Carney \\ John Molson School of Business \\ Concordia University \\ mcarney@jmsb.concordia.ca \\ Eric R. Gedajlovic \\ Faculty of Business Administration \\ Simon Fraser University \\ erg@sfu.ca \\ Pursey P. M. A. R. Heugens \\ Rotterdam School of Management \\ Erasmus University \\ pheugens@rsm.nl \\ Marc van Essen \\ Utrecht School of Economics \\ Utrecht University \\ $\underline{\text { m.essen@uu.nl }}$ \\ J. (Hans) van Oosterhout \\ Rotterdam School of Management \\ Erasmus University \\ joosterhout@rsm.nl
}

\footnotetext{
${ }^{*}$ We thank AMJ Associate Editor Gerry Sanders and three anonymous reviewers for their guidance and support. Tammo Bijmolt, Chris Doucouliagos, and Inge Geyskens provided useful suggestions for dealing with publication outlet quality variability and sample overlap issues. Nico Dewaelheyns, Sandra Dow, Niels Hermes, Woochan Kim, Robert Lensink, Ronny Manos, Claudio Piga, and Michael Sullivan sent us additional primary studies. Any remaining mistakes are our own.
} 


\title{
BUSINESS GROUP AFFILIATION, PERFORMANCE, CONTEXT, AND STRATEGY: A META-ANALYSIS
}

\begin{abstract}
Research on business groups - legally independent firms tied together in a variety of formal and informal ways - is accelerating. Through meta-analytical techniques employed on a database of 141 studies covering 28 different countries, we synthesize this research and extend it by testing several new hypotheses. We find that affiliation diminishes firm performance in general, but also that affiliates are comparatively better off in contexts with underdeveloped financial and labor market institutions. We also trace the affiliation discount to specific strategic actions taken at the firm and group levels. Overall, our results indicate that affiliate performance reflects complex processes and motivations.
\end{abstract}


The past decade has witnessed a surge in research regarding the performance of business groups (BGs), which Khanna and Rivkin (2001) define as "firms which though legally independent, are bound together by a constellation of formal and informal ties and are accustomed to taking coordinated action" (p. 47). Three points of consensus are apparent in this body of work. First, BGs are ubiquitous in many countries with types such as Japanese Keiretsus and Zaibatsu (Gerlach, 1992), South Korean Chaebols (Chang, 2003), Latin America's Grupos Economicos (Strachan, 1976), Hong Kong's Hongs (Wong, 1996), India's Business Houses (Encarnation, 1989), Taiwan's Guanxiqiye (Numazaki, 1996), Russia’s Oligarchs (Perotti \& Gelfer, 2001) and China's Qiye Jituan (Keister, 2000) becoming emblematic of their nation's enterprise systems.

A second area of consensus is that BGs are structurally different from conglomerate organizations, described by Williamson as $\mathrm{H}-$ and M-forms (Williamson, 1975). While coordination in conglomerates takes place through the unified internal control of a portfolio of firms (Davis, Diekman, \& Tinsley, 1994), coordination in BGs relies on a more complex web of mechanisms, such as multiple and reciprocated equity, debt, and commercial ties (Gerlach, 1992) and kinship affiliation between top managers (Granovetter, 2005).

A third widely held position is that BGs owe their predominance in many countries to the existence of market failures and poor-quality legal and regulatory institutions (Granovetter, 2005). In this view, BG formation has taken place in these contexts in order to internalize transactions in the absence of reliable trading partners or legal safeguards to guarantee transactions between unaffiliated firms (Khanna \& Palepu, 1997; Leff, 1978).

Despite these points of consensus, disagreement fueled by ambiguous research findings is apparent over the general question of whether or not the net economic and social effects of BGs are positive (Fisman \& Khanna, 2004; Keister, 2000). Such disagreement is evident in 
characterizations of BGs by scholars as either 'heroes or villains' (Claessens, Djankov, \& Lang, 2000a), 'paragons or parasites' (Khanna \& Yafeh, 2007), 'red barons or robbers barons' (Perotti \& Gelfer, 2001), or 'anachronisms or avatars' (Granovetter, 2005). Specifically, a lack of consensus exists on four key issues regarding BG performance and strategies.

First, researchers are divided regarding the performance implications of BG affiliation (Claessens, Fan, \& Lang, 2006; Khanna \& Palepu, 2000b). While some scholars theorize that the net effect of affiliation on profits is positive, others argue that it is negative for some or all firms, and each can point to empirical support for their positions. Researchers using exchange theory (Keister, 2001), transaction cost analysis (Luo \& Chung, 2005; Mahmood \& Mitchell, 2004), and the resource-based view (RBV) of the firm (Guillén, 2000) find that affiliation enhances performance (Almeida \& Wolfenzon, 2006; Chang \& Hong, 2000). Yet others have found that these potential advantages are often not realized due to various offsetting costs of affiliation (Claessens et al., 2006; Lee, Peng, \& Lee, 2008). A third group of scholars have found that the relationship between affiliation and performance is not universal, and that some firms within a BG benefit at the expense of others (Bertrand, Mehta, \& Mullainathan, 2002; Khanna \& Yafeh, 2005). The effect of affiliation on performance therefore remains an open question.

Second, uncertainty also exists regarding the institution-level variables which moderate the affiliation-performance relationship. The prevailing viewpoint is that BG affiliation benefits firms most in developing contexts characterized by voids in hard (i.e. telecommunication and transportation) and soft infrastructure (i.e. legal and financial systems) (Khanna \& Palepu, 1997; Fisman \& Khanna, 2004), but the evidence on this point is inconclusive. In a study of BG affiliation in fourteen emerging economies, Khanna and Rivkin (2001) find that affiliation is beneficial in six countries, detrimental in three others, and ineffectual in the remaining five. They 
conclude that the performance effects of BG affiliation "resist any simple normative categorization" (p. 68) and that a definitive understanding of their effects in various national contexts "must await further data collection and empirical inquiry" (p. 68).

Third, while many studies have examined the performance consequences of affiliation, there is a shortage of research examining the strategies of BG affiliates. As a result, there is little evidence on the issues of whether the strategies of affiliate firms are different from non-affiliated firms, and if so, whether these distinctive strategies affect the relationship between affiliation and financial performance. A clearer understanding of affiliate strategic behavior may therefore shed new light on the ambiguous findings regarding the profit impact of BG affiliation.

Fourth, the evidence concerning BG performance has primarily been drawn from studies at the affiliate rather than the group level (but see: Chang \& Hong, 2002; Luo \& Chung, 2005; Mahmood \& Mitchell, 2004). This is concerning because some of the main theoretical arguments suggesting superior BG performance emphasize their aggregate scale and scope efficiencies. For instance, it is widely argued that the performance advantages of BGs are a function of their market power and capacity to wield political influence (Morck, Wolfenzon, \& Yeung, 2005; Claessens, Djankov, \& Lang, 2000b). Similarly, Khanna and Palepu's core argument also pertains to the group level of analysis, as the success of BGs in emerging markets is attributed to their ability to mimic market institutions (Khanna \& Palepu, 1999, 2000b). Thus, there appears to be a disconnect in the BG literature between theories which emphasize group-level phenomena and empirical studies which examine performance at the affiliate level.

In short, in reviewing the literature we find that there is broad agreement among scholars that BGs are a phenomenon of great theoretical and practical import, but also important points of contention and ambiguity regarding their financial performance and strategies. The purpose of 
this study is to shed new light on these areas of dissensus with the help of several meta-analytic techniques. As noted by Eden (2002), meta-analyses are useful in addressing open research questions with data that are closer to definitive than those reported in any single primary study. As a point of departure, we perform such a research-synthesizing meta-analysis to examine the mixed empirical findings in the BG literature on the performance effects of affiliation. However, both Eden (2002) and Combs, Ketchen, Crook, and Roth (2010) point out that meta-analyses are also a useful theory-extension tool. We therefore also employ a set of more advanced metaanalytic techniques to evaluate several hypotheses that are difficult to assess in single-sample primary studies and have thus far eluded empirical scrutiny. These theory-extending hypotheses examine both moderating effects of institutional variables and mediating effects of affiliate- and group-level strategy variables on which the existing BG literature is largely silent.

\section{THEORY AND HYPOTHESES}

\section{Performance Effects of Business Group Affiliation}

To explain their prevalence in different host societies, researchers adopting various theoretical perspectives have argued that BG ties have performance-enhancing benefits for affiliates (Yiu, Lu, Bruton, \& Hoskisson, 2007). Taking up the theme of BGs as a response to market failures, Khanna and Palepu (1997) have reasoned that affiliation benefits firms because BGs function as efficient internal capital and labor markets and as an intermediary organizational form capable of mobilizing valued resources. Guillén (2000) argues that the recurring transactions between BG affiliates lead to richer flows of information that improve resource allocation and allow affiliates to acquire financial resources on favorable terms. Similarly, transaction cost theorists 
argue that scarce skilled labor and managerial talent can be developed and shared across affiliate firms more efficiently due to transaction recurrence (Chang \& Choi, 1988; Chang \& Hong, 2000). Adopting a social network perspective, other scholars have emphasized benefits arising from enduring and multiplicitous relations between BG affiliates (Gerlach, 1992; Granovetter, 2005). They argue that network embeddedness provides firms with rich formal and tacit information about each other, which offers benefits in terms of uncertainty reduction, contract enforcement, and opportunity identification (Granovetter, 2005). Gerlach (1992) and Keister (1998) reason that BGs reduce uncertainty for affiliates through the coordination of investment decisions and by providing assurances about the supply of intermediate goods. Weidenbaum and Hughes (1996) attribute the success of BGs to their informal contract enforcement capacities with regard to credit granting and joint venture participation. Luo and Chung (2005) emphasize that ongoing relations provide a conduit for the dissemination of timely information about market and technological developments that may form the basis for new business opportunities.

But other scholars argue that BGs do not exist to improve affiliate profitability (Kim, Hoskisson, \& Wan, 2004; Morck \& Yeung, 2003). Agency theorists see BGs as fraught with agency costs (Morck et al., 2005) and as instruments used by wealthy families to appropriate private benefits through a variety of tactics. These include 'pyramiding' - the control of many businesses with limited capital investments through a set of cascading parent-affiliate relationships (Claessens et al., 2000b) and 'tunneling' - a process where dominant shareholders transfer assets or profits from peripheral to core firms in which they hold relatively greater equity ownership (Friedman, Johnson, \& Mitton, 2003). Others suggest that BGs promote the stability rather than the maximization of returns (Gerlach, 1992). In this view, BGs serve as an insurance policy that reduces bankruptcy risk for affiliates, but also imposes costs or 'taxes' on members 
(Ferris, Kim, \& Kitsabunnarat, 2003), such as the obligation to prop up weaker partners (Morck \& Nakamura, 1999). Reflecting this dissensus, we propose two competing hypotheses:

Hypothesis la: Business group affiliation is positively related to a firm's financial performance.

Hypothesis 1b: Business group affiliation is negatively related to a firm's financial performance.

\section{The Moderating Role of Institutional Context}

Broad agreement exists that BGs emerged as a response to underdeveloped institutions or 'institutional voids' (Khanna \& Palepu, 1997) in developing economies, and that BG ties are beneficial in societies where such voids continue to exist (Carney \& Gedajlovic, 2002). The institutional voids thesis states that BGs internalize activities that otherwise fail to materialize due to limitations in a society's financial, legal, and labor market institutions, which jeopardize the exchange of products and services between arm's length transactors (Leff, 1978). In such contexts, BG ties are beneficial because they provide a safe haven from institutional voids and offer access to resources that are unavailable to unaffiliated firms (Khanna \& Palepu, 1997).

While theoretical support for the institutional voids thesis is widespread, less agreement exists about the relative importance of different types of voids. While some scholars focus primarily on deficiencies in financial systems, others emphasize the importance of deficiencies in legal or labor market institutions. Among the former, BGs are viewed as relatively efficient internal capital markets (Almeida \& Wolfenzon, 2006) that remedy impediments to economic growth for their affiliates, such as illiquid equity markets, limited disclosure, and the absence of market intermediaries (Khanna \& Palepu, 2000b). This view is supported by studies documenting the reliance of affiliates on group-specific financial institutions (Keister, 1998; 
Weinstein \& Yafeh, 1998) and those exploring how BGs transfer financial resources from cash rich to financially constrained affiliates (Lee et al., 2008; Lins \& Servaes, 2002).

Others have focused on deficiencies in legal institutions, which make formal contracts difficult to enforce and the exchange of products and services prone to opportunism (Hoskisson, Canella, Tihanyi, \& Faraci, 2004). In this view, BGs serve as a haven where contracts are more easily enforced and the risk of opportunism is limited. Evidence supporting this view comes from researchers describing how transaction recurrence among BG affiliates provides rich information flows, reputation effects, and informal contract enforcement mechanisms which curb opportunism (Berglöf \& Perotti, 1994; Guillén, 2000; Khanna \& Palepu, 1997).

Lastly, another group of scholars highlight the roles played by BGs in societies where there are weaknesses in institutions supporting the development of human capital such as deficient general, technical, and professional schools, which can lead to acute labor shortages (Fisman \& Khanna, 2004). In these contexts, BGs may alleviate shortages by functioning as internal labor markets, investing in training and development (Khanna \& Palepu, 2000a; Lincoln \& Gerlach, 2004) and dispatching scarce talent to needy affiliates (Lincoln \& Gerlach, 2004).

Conceptually, institutional voids are best thought of as moderating variables affecting the relationship between affiliation and performance. Institutional voids theory (Khanna \& Palepu, 1997, 2000a) suggests that financial, legal, and human resource voids will not influence all firms equally. Rather, such voids impose a stronger negative performance effect on standalone firms due to the various benefits affiliates receive, such as the mutual assistance that group members can offer one another. The relationship between affiliation and firm performance is therefore expected to become stronger in a positive direction as institutional voids increase in magnitude. The following three hypotheses capture these moderation effects: 
Hypothesis 2a: The associational strength of the relationship between business group affiliation and financial performance is positively moderated by the existence of weak financial infrastructure.

Hypothesis 2b: The associational strength of the relationship between business group affiliation and financial performance is positively moderated by the existence of weak legal institutions.

Hypothesis 2c: The associational strength of the relationship between business group affiliation and financial performance is positively moderated by the existence of weak labor market institutions.

\section{The Mediating Role of Organizational Strategy}

Whereas many scholars have examined the affiliation-performance relationship, only few have looked at the effects of affiliation on firm strategy (e.g. Colpan, 2006; Lamin, 2006), and none have examined the mediating role that strategy plays in the focal relationship. Consequently, the literature is largely silent on the important questions of whether BG affiliates make distinctive strategic choices, and if so, whether these choices explain performance differences between affiliated and non-affiliated firms. Yet affiliates' strategies are likely to differ from those of standalone firms on at least three dimensions: leverage, diversification, and internationalization. We expect these strategic choices to reflect a wider set of motives than profit maximization alone, such that affiliates may face a performance discount relative to unaffiliated firms.

Leverage. Four streams of literature suggest that $\mathrm{BG}$ affiliates make greater use of debt financing than non-affiliates. First, agency theorists argue that affiliates' majority shareholders prefer to finance operations through debt rather than issuing new equity, which dilutes their 
effective control (Berglöf \& Perotti, 1994). Second, the internal capital markets thesis suggests that affiliates are more leveraged because they have access to sources of debt unavailable to nonaffiliates (Keister, 2001). Third, norms of mutual assistance that other researchers have described as emblematic of BG affiliation may function as an "insurance policy" (Lincoln, Gerlach, \& Ahmadjian, 1996), lessening bankruptcy risk and promoting leverage. Fourth, the thick web of information connecting affiliates facilitates monitoring and the detection of default risk, making the intra-group provision of debt less risky for lenders (Gedajlovic \& Shapiro, 2002).

While there are no studies investigating the performance consequences of debt-reliant financial strategies in the context of BGs, there may be a bias among BG affiliates to invest in too many projects or in projects of the wrong type, as both privileged access to debt and the coinsurance effect of affiliation may promote unwieldy growth (Whited, 2001). Similarly, both the group norms described by sociologists (e.g. Gerlach, 1992) pertaining to the expectation of supporting fellow affiliates and the majority shareholder entrenchment effect described by agency theorists (Faccio, Young, \& Lang, 2001) suggest that debt financing may be used to fund projects for reasons other than profit maximization. Higher leverage by BG affiliates is therefore expected to lead to lower performance relative to standalone firms.

Diversification. We expect BG affiliates to engage in more unrelated diversification than other firms for three reasons. First, agency theorists suggest that many investments by BGs and their affiliates are driven more by controlling shareholders' attempts to appropriate wealth through pyramiding and tunneling than by the profit potential of these investments (Bertrand et al., 2002; Friedman et al., 2003). Second, the availability of financing from a group's internal capital market insulates the firm from external scrutiny and capital market pressures that constrain unrelated diversification in public corporations (Almeida \& Wolfenzon, 2006; Keister, 
2001). Third, sociological perspectives suggest that the investment activity of affiliates is driven more by the needs of the group than by their own requirements, leading to their involvement in activities that unaffiliated firms would not take part in (McGuire \& Dow, 2009). Given the significant bureaucratic and coordination costs associated with the management of diverse operations (Hoskisson, Johnson, Tihanyi, \& White, 2005), we expect that these tendencies toward unrelated diversification will negatively influence affiliate-level financial performance.

Internationalization. The literature suggests three reasons for a less pronounced international orientation amongst BG affiliates relative to non-affiliated firms (Colpan, 2006; Lamin, 2006; Hundley \& Jacobson, 1998). First, the specialized services that BGs provide to remedy the institutional voids of their home countries may be more valuable domestically then abroad. Second, many of the potential benefits of affiliation are grounded in the group's network of social and economic ties (Lamin, 2006). As such network benefits are strongest in a firm's home market, they may result in a more domestic orientation among BG affiliates. Third, social norms in many BGs dictate that firms should first look amongst other affiliates for possible buyand-supply relationships before approaching non-group members, which may engender “complacency and a reduced incentive to export" (Hundley \& Jacobson, 1998: 935).

Even though BG affiliates enjoy advantages in accessible financial resources (Khanna \& Palepu, 1997; Guillén, 2000), their preferences for domestic projects may lead them to pass on international opportunities which are viewed as profitable by unaffiliated firms. That is, unconstrained by the social-structural forces and behavioral norms associated with group membership, unaffiliated firms can more readily exploit international projects, allowing them to more freely tap into new markets and leverage their existing capabilities. Conversely, the domestic orientation of BG affiliates may lead to performance lagging that of standalone firms. 
In sum, multiple theoretical perspectives suggest that the strategies of BG affiliates will differ from non-affiliates, explaining some of the performance differentials between them. These views are expressed in the following hypothesis:

Hypothesis 3: The relationship between business group affiliation and affiliate financial performance is mediated by the unique financing, diversification, and internationalization strategies of business group affiliates.

\section{Group-Level Performance Effects.}

Our focus thus far has been on the strategic and performance consequences of group membership for BG affiliates rather than on the performance of the group as a whole. This affiliate-level focus is dominant in empirical BG work. We reason that the relative inattention paid to grouplevel effects is related to difficulties associated with developing a sufficiently large sample of BGs in any single primary study. Such pragmatic considerations have led to a disconnect between theoretical work on BGs, which focuses on group-level processes such as the ability to amass market power and perform intermediating functions, and empirical work, which examines such processes using affiliate-level data. The meta-analytic nature of our study allows us to surmount such data availability problems related to the evaluation of group-level processes.

BG size is widely viewed as an important factor explaining group performance, but researchers have offered very different explanations regarding why size matters. In our treatment of BG size, we strive for greater precision by explicitly distinguishing between the related effects of scale and scope on BG performance. By making this distinction, we are able to consider how and why BGs grow and also differentiate between various processes linking BG size to 
performance outcomes. In doing so, we account for the possibility that BG scale and BG scope have differing effects on group-level performance.

It is widely believed that BGs of a larger scale enjoy performance enhancing advantages relative to smaller groups (Guillén, 2000; Khanna \& Yafeh, 2007). There is a strong impetus for sales and asset growth in BGs for a number of reasons. First, larger BGs can benefit from economies of scale, allowing them to more cost-effectively carry out value-creating intermediating functions (Khanna \& Palepu, 2000a), such as administrative and project management activities (Amsden \& Hikino, 1994). Second, increased scale may afford BGs reputation-enhancing effects. For instance, Morck, Wolfenzon, and Yeung (2005) argue that larger BGs may benefit from a reputation for fair dealing with business partners, and Khanna and Palepu (2000b) reason that reputation effects provide larger BGs with superior access to foreign capital and technological resources. Third, increased scale can provide BGs with a variety of benefits tied to enhanced market (Khanna \& Yafeh, 2007; Mackie, 1992; Yoshihara, 1988) and political power (Carney, 2004; Claessens et al., 2000a; Dielemans \& Sachs, 2008). For these reasons, we hypothesize that BG scale is positively related to group-level performance.

Hypothesis 4a: Business group operational scale is positively related to business group financial performance.

While the arguments summarized in relation to Hypothesis 4a suggest there is a strong impetus for sales and asset growth in BGs, they do not distinguish between the various types of activities that may be pursued to achieve that greater scale. At a fundamental level, like executives elsewhere, BG managers face decisions regarding whether to grow their operations by 
increasing their commitment to existing product markets, or by expanding the scope of their activities by entering new lines of business. In this respect, the literature suggests that the pull towards increasing size through growth in the scope of activities will be especially strong in BGs because of the types of leverageable resources they control, as well as the nature of the new business opportunities available to them (Guillén, 2000; Khanna \& Palepu, 2000b; Kock \& Guillén, 2001). For example, Chang and Hong (2000) reason that the types of assets available to BGs allow them to assemble the resources necessary to take advantage of diverse business opportunities and Luo and Chung (2005) similarly contend that network embeddedness within BGs provides a conduit for timely information exchange, leading to the pursuit of diverse business opportunities.

Thus, researchers generally agree that growth in BGs tends to be manifested in activities that increase the scope of a group's operations and several streams of research have theorized about the performance effects of such increased scope. Hoskisson, Johnson, Tihanyi, and White (2005) contend that broader scope in BGs leads to performance-impairing challenges related to bureaucratic and coordination costs associated with the management of increasingly complex groups. Others, however, see the effects of increased BG scope in a more favorable light and argue that it can actually be profit enhancing. In particular, proponents of the institutional voids thesis suggest that broader scope allows BGs to perform interstitial functions and provide resources and support for their various businesses. Khanna and Palepu (1997), for example, argue that greater scope enables BGs to function effectively where reliable trading partners are unavailable, as it addresses their need for complimentary products and services.

The preceding discussion suggests that the impetus for sales and asset growth in BGs (cf. Hypothesis $4 a$ a) tends to manifest itself in the form of performance impacting activities that 
increase group scope. Consequently, we hypothesize that BG scope mediates the relationship between BG scale and BG performance.

Hypothesis 4b: Business group operational scope mediates the relationship between business group operational scale and business group financial performance.

\section{METHODS}

\section{Sample and Coding}

To identify relevant studies, we used five complementary search strategies (Heugens, van Essen, \& van Oosterhout, 2009). First, we consulted several review articles (e.g. Carney, 2008; Khanna \& Yafeh, 2007; Yiu et al., 2007). Second, we explored five electronic databases: (1) ABI/INFORM Global, (2) EconLit, (3) Google Scholar, (4) JSTOR, and (5) SSRN, using the following search terms: "business group," "business houses," "chaebol," "grupos economicos," "guanxiqiye," "hongs," "keiretsu," "oligarchs," "pyramids," "qiye jituan”, and "zaibatsu”. Third, we manually searched 25 scholarly journals, including Academy of Management Journal, Journal of Comparative Economics, Journal of Corporate Finance, Journal of Finance, Journal of International Business Studies, and Strategic Management Journal. Fourth, we explored the reference lists of all identified articles and traced all sources citing them using Google Scholar and ISI Web of Knowledge. Fifth, we corresponded with 54 authors of BG papers with missing effect size information, asking them for a correlation table. These efforts yielded a sample of 141 primary studies, consisting of 102 published and 39 unpublished studies (see Appendix A). 
We then read all the articles and developed a coding protocol (Lipsey \& Wilson, 2001) for extracting data on all relevant variables. To test Hypotheses 1a and 1b, we collected effect size information for the relationship between BG affiliation and firm performance, as well as sample size information. To test Hypotheses $2 \mathrm{a}, 2 \mathrm{~b}$, and $2 \mathrm{c}$, we collected covariates from secondary sources. For testing Hypotheses 3 , 4a, and 4b, we collected effect size information for interrelationships between all dependent, independent, and control variables in our analyses.

\section{HOMA Procedure}

We used HOMA to test Hypotheses 1a and 1b. HOMA refers to a set of statistical procedures for calculating meta-analytic mean correlations and corresponding confidence intervals (Hedges \& Olkin, 1985; Lipsey \& Wilson, 2001). HOMA inputs are effect sizes capturing the strength of the focal relationship in a given sample, such as the Pearson product-moment correlation $r$ or the partial correlation coefficient $r_{x y . z}$. In this study we rely on both $r$ and $r_{x y . z}$. We use $r$ because it is a widely published effect size statistic in management. Yet $r$ is a bivariate measure of association, which ignores the effect of other variables that are often used as controls in multivariate investigations of the focal relationship. We therefore also use $r_{x y . z}$, which can be computed directly from regression tables (Doucouliagos \& Ulubaşoğlu, 2008). In our case, $r_{x y . z}$ captures the association between BG affiliation $\left.{ }_{X}\right)$ and affiliate performance ${ }_{Y}$ ), given a set of $n$ controlling variables (z). ${ }^{\dagger}$ The $z$-vector typically contains control variables like firm size, age, and risk.

\footnotetext{
${ }^{\dagger}$ Partial correlations are computed as follows: $\sqrt{ }\left(\mathrm{t}^{2} /\left(\mathrm{t}^{2}+\mathrm{df}\right)\right)$, where $\mathrm{t}$ is the $\mathrm{t}$-statistic and $\mathrm{df}$ is degrees of freedom. As this will always produce a positive number, it is necessary to convert it to a negative number if the regression coefficient is negative (see: Greene, 2008, Chapter 3). t-values result from the scaling of primary coefficients by their respective standard errors. They are by definition standardized and defined on a dimensionless scale.
} 
When studies reported effect size statistics other than $r$ or $r_{x y . z}$, such as Cohen's $d$, we converted these to an $r$ value (Lipsey \& Wilson, 2001). When multiple measurements of the focal effect were reported, we included them all in our analyses, as Monte Carlo simulations show that procedures using the complete set of measurements outperform those representing each study by a single value in areas like parameter significance testing and parameter estimation accuracy (Bijmolt \& Pieters, 2001). Since HOMA procedures assume that effect sizes are normally distributed, we used Fisher's (1928) $Z r$-transformation to correct for skewness in the effect size distribution (Hedges \& Olkin, 1985). In line with current conventions, we used random-effects HOMA for combining study estimates (Geyskens, Krishnan, Steenkamp, \& Cunha, 2009; Raudenbush \& Bryk, 2002). To estimate mean effects appropriately, differences in precision across effect sizes have to be accounted for, so we weighted them by their inverse variance weight $w$ (Hedges \& Olkin, 1985): the inverse of their squared standard error. We also used these weights to calculate the standard error of the mean effect and its confidence interval. ${ }^{\S}$

${ }^{\ddagger} w$ is calculated as follows: $w_{i}=\frac{1}{s e_{i}^{2}+\hat{v}_{\theta}}$, where SE is the standard error of the effect size and $\hat{v}_{\theta}$ is the random effects variance component., which is in turn calculated as: s.e. $\left(z_{r}\right)=\frac{1}{\sqrt{n-3}}$, and the formula of random effect variance is: $\hat{v}_{\theta}=\frac{Q_{T}-k-1}{\sum w-\left(\frac{\sum w^{2}}{\sum w}\right)}$

$\S$ The meta-analytic mean is calculated as follows: $\overline{E S}=\frac{\sum(w \times E S)}{\sum w}$, with its standard error: $s e_{\overline{E S}}=\sqrt{\frac{1}{\sum w}}$, and with its $95 \%$ confidence interval computed as: $L o w e r=\overline{E S}-1.96\left(s e_{\overline{E S}}\right)$, Upper $=\overline{E S}+1.96\left(s e_{\overline{E S}}\right)$ 


\section{MARA Procedure}

To test Hypotheses 2a through 2c we used MARA (Lipsey \& Wilson, 2001), a special type of weighted least squares (WLS) regression analysis, designed to assess the relationship between effect size and moderator variables by modeling heterogeneity in the effect size distribution (Lipsey \& Wilson, 2001). In MARA, effect sizes are weighted by $w$ to account for differences in precision (Hedges \& Olkin, 1985). MARA is a modified type of WLS regression, which prevents statistical analysis programs from interpreting these weights as "representing multiple effect sizes rather than weightings of single effect sizes" (Lipsey \& Wilson, 2001: 122). As scholars are concerned about the inaccuracy of fixed-effects models (Geyskens et al., 2009), we use a more conservative mixed-effects specification, which attributes effect size variability to systematic between-study differences, firm-level sampling error, and an unmeasured random component (Lipsey \& Wilson, 2001). The moderator variables we use capture aspects of the institutional context from which effect sizes were drawn as well as methodological study characteristics.

To test the moderating effects of local institutions, we collected data from additional sources and employed them in conjunction with those obtained from the primary studies. We used two variables to assess the impact of financial infrastructure (Hypothesis 2a). The availability of equity capital was measured by dividing each country's total stock market capitalization by its gross domestic product. Ease of obtaining debt financing was taken from the IMD World Competitiveness Yearbook. Three variables were used to capture the effects of legal institutions (Hypothesis 2b). To measure the overall quality of legal institutions, we used Kaufmann, Kraay, and Mastruzzi's (2005) 'rule of law' measure. We assessed the level of legal protection against self-dealing with Djankov, La Porta, López-de-Silanes, and Shleifer's (2008) 'anti-self-dealing index.' To measure the efficiency of the legal system in resolving commercial 
disputes, we used the Doing Business (World Bank) 'enforcing contracts' indicator. We utilized four variables to measure the effect of labor market institutions (Hypothesis 2c). We used World Development Indicator (World Bank) data to assess the general education level. To measure the availability of professionally trained managers, we created a new variable by counting the number of the Association to Advance Collegiate Schools of Business (AACSB) accredited business schools in each country (AACSB membership data). To assess the quality of these schools, we consulted the Global Competitiveness Report (World Economic Forum). The same report also provided a measure capturing overall labor market competitiveness.

We also employed seven control variables to establish the robustness of our hypothesis tests. First, we used a dummy variable capturing whether particular effect sizes were derived from published (' 1 ') or unpublished ('0') studies. Second, a dummy variable indicating whether a study utilized cross-sectional (' 1 ') or longitudinal ('0') data was used. Third, to account for differences in journal quality, we controlled for impact factor (ISI Web of Knowledge ${ }^{s m}$ ) of the publication outlet, assigning a value of ' 0 ' to unpublished or non-ISI sources and the actual impact factor otherwise. Fourth, to control for potential time-dependence (cf. Khanna \& Yafeh, 2007), we coded the year of data collection for each effect size, taking the median sampling year for longitudinal designs. Fifth, to control for voids in physical infrastructure (cf. Fisman \& Khanna, 2004), we compiled a new composite index based on five indicators related to 'railroads,' 'ports,' 'air transport,' 'electricity supply,' and 'phone lines' from the Global Competitiveness Report. Sixth, to control for the high proportion of Japanese data in the primary studies, we used a dummy variable segregating Japanese ('1') from other ('0') effect sizes. Seventh, to control for (partial) overlap in sampling time frames across studies, we included dummy variables for each set of studies relying on similar data. 


\section{MASEM Procedure}

To test Hypotheses 3, 4a, and 4b, we used MASEM (Cheung \& Chan, 2005; Viswesvaran \& Ones, 1995), which uses a two-stage procedure. First, mean correlations between variables of interest are established through separate HOMA analyses. Second, structural equations modeling is applied on the matrix of mean correlations, using maximum likelihood modeling routines (Cheung \& Chan, 2005). MASEM has two advantages over other meta-analytic techniques. First, not all relationships specified by the theory under investigation need to be included in each primary study, as each cell in the data matrix represents a different subset of all included studies (Viswesvaran \& Ones, 1995). Second, MASEM can be used to test previously untested research hypotheses, especially those such as Hypotheses 3, 4a, and 4b, which stipulate mediating relationships connecting two previously unlinked literatures (Eden, 2002).

Testing Hypothesis 3 requires us to assess: (a) the direct effect of BG affiliation on firm performance; (b) the effect of affiliation on firms' revealed strategy choices; and (c) the consequences of these choices for firm performance. The included strategic choice variables are: leverage (ratio of total debts to total assets), diversification (Herfindahl or entropy measure capturing presence in multiple business segments), and internationalization (ratio of exports to total sales). We also control for the influence of firm size (total assets, sales, or employees) and firm age (years since founding) on strategy choices, and of firm risk (volatility of returns) and $R \& D$ intensity (ratio of $R \& D$ expenditures to total sales) on affiliate performance. Due to the potential endogeneity of firms' strategy and affiliation choices on performance (cf. Khanna \& Palepu, 1997), independent tests of these effects could introduce biased estimates. We therefore tested the following system of simultaneous equations: 
(1) Diversification $=\beta_{1}$ affiliation $+\beta_{2}$ size $+\beta_{3}$ age $+\varepsilon$

(2) Internationalization $=\beta_{4}$ affiliation $+\beta_{5}$ size $+\beta_{6}$ age $+\varepsilon$

(3) Leverage $=\beta_{7}$ affiliation $+\beta_{8}$ size $+\beta_{9}$ age $+\varepsilon$

(4) Performance $=\beta_{10}$ affiliation $+\beta_{11}$ risk $+\beta_{12}$ research $\&$ development $+\beta_{13}$ diversification + $\beta_{14}$ internationalization $+\beta_{15}$ leverage $+\varepsilon$

Hypotheses $4 \mathrm{a}$ and $4 \mathrm{~b}$ call for a test of: (a) the direct effect of $\mathrm{BG}$ scale on $\mathrm{BG}$ performance; (b) the effect of BG scale on BG scope; and (c) the influence of BG scope on BG performance. BG scale is measured as the sum of assets, sales, or employees across all affiliates; BG scope as a Herfindahl index or entropy measure capturing BG presence in multiple business segments. We also control for the influence of group leverage, R\&D intensity, and risk on BG performance. Due to the potential endogeneity of BG scale and BG scope on BG performance, biased estimates could result from independent tests of these effects (Khanna \& Palepu, 2000b; Kock \& Guillén, 2001). We therefore evaluated the following simultaneous equations:

(1) Scope $=\beta_{1}$ scale $+\varepsilon$

(2) Performance $=\beta_{2}$ scale $+\beta_{3}$ scope $+\beta_{4}$ leverage $+\beta_{5}$ research \& development $+\beta_{6}$ risk $+\varepsilon$

Both systems of equations were estimated on firm- and group-level meta-analytic correlation matrices, using the full information maximum likelihood method in LISREL 8.80. To deal with sample size differences across the correlation coefficients comprising these matrices, we based our analyses on harmonic mean sample sizes (firm level: $N=7,065$; group level: $N=16,353$ ). 


\section{RESULTS}

\section{Firm-Level Bivariate and Partial Correlations}

Tables 1 and 2 show that Hypothesis 1a should be rejected in favor of Hypothesis 1b: the mean correlation of the focal relationship is -.02 for both the bivariate $(k=284)$ and partial correlation $(k=50)$ HOMAs. As the confidence intervals do not include zero, the effects are significant.

Insert Tables $1 \& 2$ about here

Three caveats apply, however. First, the control group of unaffiliated firms is not identical to the treatment group in terms of either prevalence or size. Across all included studies, affiliated firms represent 34 percent of the sample (see Table 3). Furthermore, a HOMA on the relationship between BG affiliation and firm size yields a strong correlation $(.26 ; k=164)$, so we control for size in all firm-level analyses. Second, the results in Table 1 suggest that the strength of the focal relationship is driven by the chosen performance measure. Affiliation is negatively related to accounting performance (-.03; see Table 1), implying that affiliates are less profitable than standalone firms. On the other hand, tests using market-based measures of performance reveal no significant effect (-.01, n.s.). Third, the mean effects we found are small by conventional standards (Cohen, 1977), implying that the effect of affiliation is modest. Furthermore, the amount of (true) heterogeneity present in both effect size distributions is substantial ( $r$-based: $Q$ $=5,805.29 ; p<.01 ; I^{2}=.95 ; r_{x y . z}$-based: $\left.Q=252.36 ; p<.01 ; I^{2}=.80\right)$. Under these conditions, mean effects are best interpreted as an average rather than a common true correlation value (Hedges \& Olkin, 1985: 235), implying that further moderator analyses are warranted.

We also conducted three robustness checks. First, the primary studies in our sample 
derive from journals of varying status. To control for these differences, we ran separate $r$-based HOMAs on effect sizes derived from: published studies $(k=180)$, journals with an editorial team dominated by US- or Western Europe-based scholars $(k=173),{ }^{* *}$ peer reviewed publications $(k=$ 159), journals included in the ISI Social Science Citation Index (SSCI) in $2008(k=123)$, journals continuously included in SSCI from $2004-2008(k=118)$, journals with an SSCI impact factor greater than $>1.0(k=109)$, and the 10 journals in our dataset with the highest five-year SSCI Impact Factors $(k=44)$. All mean correlations are significant and between -.02 and -.03 , suggesting that publication outlet quality does not moderate the focal relationship.

Second, some of the samples in our analysis overlap in terms of included firms and time periods, which could result in similar correlation structures between same-country samples. We used several checks to diagnose the severity of this 'drinking from the same well' problem. In a separate HOMA, we included only the largest non-overlapping samples per country $(k=51)$. At -.04 , this result is materially similar to the overall mean correlation. We also ran two separate MARAs (see Table 4): one with dummy variables for each set of overlapping samples (Model 1), and another in which other control variables were also included (Model 2). In both cases, the model constant (i.e., the control variable-adjusted mean correlation) was -.03 . Two $z$-tests for meta-analytic mean differences (Feingold, 1992) corroborate that the corrected and uncorrected mean correlations are not significantly different (see Table 4). In short, the 'drinking from the same well' issue does not appear to affect our results.

Third, because BGs are prominent in Asia, we assessed whether the financial crisis that struck that continent in 1997-1998 (Mitton, 2002) affected our findings. We split our sample into four sub-groups: observations from the pre-crisis period (prior to 1996); the crisis period (1997

\footnotetext{
** This distinction was suggested by one of our reviewers.
} 
and 1998); the post-crisis period (1999 and after); and the 'mixed' category of observations covering two or more of these periods. Separate $r$-based HOMAs show that our findings are robust against the effects of the crisis (pre-crisis: -.04, $k=105$; crisis: -.02 (n.s.), $k=20$; postcrisis: $-.02, k=75$; mixed: $-.02 ; k=84)$.

\section{Jurisdiction-Level Moderating Effects}

Table 3 reports country-specific $r$-based HOMA results. ${ }^{\dagger}$ The effect of affiliation on performance is positive in six countries: Chile, Colombia, Hong Kong, Indonesia, Sweden, and Turkey. It is negative in five others: France, Japan, Nigeria, Pakistan, and South Korea. No significant affiliation effect exists in seven other countries: Belgium, China, India, the Philippines, Russia, Taiwan, and Thailand. We could not estimate a separate mean effect for the remaining nine countries, due to a lack of observations. Table 4 shows three MARA models. Models 1 and 2 report results for data source quality and other controls. Model 3 reports results for Hypotheses 2a, 2b, and 2c. Model 3 fits the data well $\left(R^{2}=.28 ; Q_{\text {model }} p<.01\right)$.

Insert Table $3 \& 4$ about here

The results support Hypothesis 2a. The development of a jurisdiction's financial infrastructure, captured by debt availability and stock market capitalization, negatively moderates the affiliation effect. When external financing is not easily available, affiliation becomes relatively more advantageous because a BG's internal capital market can be turned to for financing. Hypothesis $2 \mathrm{~b}$ is rejected. The quality of business-relevant legal institutions, as captured by the rule of law,

\footnotetext{
† One of the countries comprising our sample (Italy) is not included in Table 3, as we retrieved correlations between our independent (MASEM) variables for it, but not for the focal relationship.
} 
anti-self-dealing, and enforcing contracts variables, does not negatively moderate the focal relationship. In contrast, the rule of law index positively moderates it, indicating that without access to effective courts the performance of BG affiliates suffers. This suggests that inefficient resource allocation decisions caused by agency problems like tunneling or propping may more negatively impact firm performance in contexts with weak overall legal protection (Bae, Kang, \& Kim, 2002; Johnson, Boone, Breach, \& Friedman, 2000). Hypothesis 2c is supported. The quality of labor market institutions, as captured by general education level, and the business school count and quality variables, negatively moderates the focal relationship. BG affiliation is more advantageous in contexts characterized by labor market voids. No significant effect was found for overall labor market competitiveness, however, suggesting that groups are better at filling specific rather than generic voids.

Table 4 also reports control variable results. Publication status and research design did not moderate the focal effect. The significant negative effect for median sample year suggests that BG affiliation becomes less beneficial over time (cf. Khanna \& Palepu, 2000a). Journal impact factor moderated the focal relationship negatively, implying a modest publication bias amongst more highly cited journals. Finally, the physical infrastructure variables were not significant, implying that BGs are not effective at filling 'harder' infrastructural voids. Finally, the Japan dummy has a significant negative moderating effect.

\section{Firm-level Mediating Effects}

Table 5 shows a firm-level meta-analytic correlation matrix. All 36 cells below the diagonal contain a separate meta-analysis, indicating both the mean effect and its standard deviation (s.d. $\rho$ ). Cells above the diagonal report the number of primary observations $(N)$ and samples $(k)$ on 
which the mean effect is based. For entries printed in bold, a significant $Q$-test indicates the presence of moderating variables, suggesting that the reported value is an average rather than a common true correlation value (Hedges \& Olkin, 1985: 235).

Table 6 presents firm-level MASEM results. MASEM addresses simultaneity issues with respect to affiliation and strategy choices and incorporates control variables. As such, it offers a more precise test of Hypothesis 3 than the bivariate analyses reported in Table 5. The model fits the data well $\left(\chi^{2}=760.09 ;\right.$ RMSR $=.10 ;$ GFI = .98). Furthermore, all conditions for mediation are met (Baron \& Kenny, 1986). First, BG affiliation significantly affects all three hypothesized mediators: diversification $(\beta=.06)$, internationalization $(\beta=-.09)$, and leverage $(\beta=.05)$. Second, BG affiliation significantly affects firm performance in the absence of these mediators (.02 ; see Table 5). Third, two out of three mediators have a significant effect on firm performance: diversification $(\beta=-.05)$, internationalization $(\beta=.01$; n.s. $)$, and leverage $(\beta=-.12)$. Fourth, the effect of affiliation on performance shrinks when the mediators are added to the model (to $\beta=$ .01 ; n.s). Formal tests (MacKinnon \& Dwyer, 1993) confirm that mediating variables carry the influence of BG affiliation to firm performance (Sobel test: $z=3.77 ; p<.01$; Aroian test: $z=$ $3.75 ; p<.01$; Goodman test: $z=3.80 ; p<.01)$. Thus, Hypothesis 3 is supported by the data.

\section{Insert Tables $5 \& 6$ about here}

\section{Group-Level Mediating Effects}

Table 7 presents a group-level meta-analytic correlation matrix, consisting of 15 separate HOMAs. These results confirm Hypothesis 4a: BG scale has a significant positive effect on BG performance (.07). Table 8 shows the group-level MASEM results. This model fits the data well $\left(\chi^{2}=172.10 ; \mathrm{RMSR}=.02 ; \mathrm{GFI}=.99\right)$, and all remaining conditions for mediation are met 
(Baron \& Kenny, 1986). First, BG scale has a substantial and significant positive effect on BG scope $(\beta=.47)$. Second, BG scope has a significant unique effect on BG performance $(\beta=-.13)$. Third, the positive effect of BG scale on BG performance increases when BG scope is added to the model (to $\beta=.09$ ). Formal tests (MacKinnon \& Dwyer, 1993) confirm the mediating role of the BG scope variable (Sobel test: $z=15.26 ; p<.01$; Aroian test: $z=15.26$; $p<.01$; Goodman test: $z=15.27 ; p<.01)$, thereby supporting Hypothesis $4 \mathrm{~b}$.

\author{
Insert Tables $7 \& 8$ about here
}

\title{
DISCUSSION AND DIRECTIONS FOR FUTURE RESEARCH
}

Scholars alternatively portray BGs as 'heroes,' 'paragons,' and 'avatars,' or as 'villains,' parasites,' and 'anachronisms' (Claessens et al., 2000a; Khanna \& Yafeh, 2007; Granovetter, 2005). Our results show that such categorical classifications are unwarranted, and that their character is considerably more complex. Specifically, our study offers four substantive contributions to the BG literature, each of which nuances the dichotomous categorical schema through which scholars and policy makers have tended to approach BGs.

First, we conducted a meta-analysis synthesizing all evidence on the effect of affiliation on performance (Geyskens et al., 2009). Whereas this effect is negative and significant, its magnitude (-.02) offers no grounds to discard BGs as a dysfunctional organizational form. Rather, our research synthesis shows that the performance implications of affiliation are very heterogeneous, and must be qualified by the moderating effects of institutional contingencies and the mediating effects of strategic actions taken by group- and affiliate-level managers. 
Second, we unpacked the notion of 'institutional voids' (Khanna \& Palepu, 1997; 2000b) by exploring the moderating effects of a broad set of theoretically derived institutional variables on the focal relationship. We revealed that affiliates perform relatively well in contexts characterized by 'soft' voids in labor and financial market institutions, but also that BGs add no value in contexts lacking 'hard' infrastructure and actually impair affiliate performance in settings with underdeveloped legal institutions. Scholars and policy makers therefore need to avoid labeling national contexts in terms like "developed," "emerging," and "developing," and instead place greater emphasis on the varied effects played by different types of institutions.

Third, we identified differences in the revealed strategic choices of BG affiliates (relative to non-affiliates) and assessed the performance implications of these choices. We found that affiliates tend to be more leveraged, diversified, and locally oriented than their standalone counterparts, which explains much of the performance discount they incur. These results both reveal previously unidentified strategic mediators (e.g. financing and product-market strategies) and point to the underexplored effect of managerial processes on affiliate performance.

Fourth, we advanced prevailing theoretical accounts of the drivers of group-level performance (e.g. Chang \& Hong, 2002; Luo \& Chung, 2005; Mahmood \& Mitchell, 2004). Whereas current theorizing often conflates various processes associated with BG size, we disentangle these into positive scale and negative scope effects. Owing to factors like size-related cost savings and increased market and political power, greater scale improves BG performance. However, greater scale also tends to broaden the operational scope of BGs which increases bureaucratic and control costs and negatively impacts their performance. Scope is therefore best seen as a mediator suppressing the otherwise positive effect of scale on group-level performance. 


\section{Complexity and Nuance in the Affiliation-Performance Relationship}

Our analyses reveal a small but significant negative relationship between affiliation and performance (cf. Hypotheses 1a and 1b). This suggests that on average the costs of BG affiliation, such as the agency problems described by Morck and Yeung (2003) and the insurance premiums discussed by Lincoln, Gerlach, and Ahmadjian (1996), slightly outweigh benefits like access to internal capital markets and dispute resolution mechanisms (Chang \& Hong, 2000; Khanna \& Palepu, 1997). However, more striking than this modest negative relationship, is the heterogeneity of the focal effect illustrated by the considerable differences found in the direction and strength of the performance effect of affiliation across national contexts (Table 3).

Thus, our findings indicate that BGs are highly variegated, complex phenomena, implying that nuanced methodologies and theories are necessary to bring their core attributes to light. In terms of methodologies, we advocate research designs adopting middle-range perspectives (Merton, 1968), centering on conceptual frameworks that are more generic than descriptive case studies of individual groups and their affiliates, but also more specific than universalistic approaches that treat all cases as essentially similar. For instance, future research may be usefully directed towards in-depth comparative studies explaining cross-national performance differentials (see Table 3). We expect that these differences can only partly be traced to variation in institutional development and that cross-country differences in the behavior of managerial actors will also prove to be an important driver of BG performance.

The theoretical frameworks used to understand BG behavior will likewise have to evolve and become more nuanced. To date, most BG studies have employed mono-theoretical lenses such as agency theory (Morck \& Yeung, 2003), transaction cost theory (Luo \& Chung, 2005), exchange theory (Keister, 2001), and the RBV (Guillén, 2000). Whereas each of these theories 
offers a useful perspective on BG behavior and performance, none of them in isolation suffices to explain this complex and variegated organizational form. Therefore, we see a need for future studies offering concurrent tests of multiple theories, as well as studies developing and testing eclectic explanatory frameworks combining variables from multiple source theories.

\section{Local Institutions and the Institutional Voids Thesis}

Our meta-analytic approach allowed us to consider a more heterogeneous set of 28 jurisdictions than any previous study (e.g. Khanna \& Rivkin, 2001) in assessing the moderating effects of institutions on the focal relationship. In addition to data obtained from earlier studies, we also collected data for 10 institutional variables pertaining to financial infrastructure as well as legal and labor market institutions. We thus considered a broader range of institutional-level variables than previous studies and explored their effects over a more inclusive set of national contexts. This allowed us to unpack the notion of "institutional voids," which has emerged as a umbrella term for a nation's stage of development (cf. Khanna \& Palepu, 1997, Khanna \& Palepu, 2000b), and our findings indicate that while some institutional-level factors moderate the focal relationship in the conventionally theorized direction, others do not.

As suggested by the institutional voids thesis, we found that firms benefited from affiliation in contexts characterized by weak financial and labor market infrastructure (Hypotheses 2a, 2b, and 2c). Yet, even though the view that affiliation benefits firms in contexts with weak legal safeguards is widely held (cf. Almeida \& Wolfenzon, 2006), we find little evidence for this position. While our results support the institutional voids thesis in general, they also suggest the need for researchers and practitioners to make finer-grained distinctions between specific types of institutional voids and their consequences for firms and economies. 
Our findings indicate that we should exercise caution in drawing broad conclusions regarding institutional development and affiliate performance. Figure 1, which combines insights from our jurisdiction-level HOMA and MARA analyses (Tables 3 and 4), testifies to the need for further middle-range theorizing. Its horizontal axis was computed by transforming the scores of a given country on all statistically significant variables capturing institutional voids (Table 4) to $z$ scores, and then adding and averaging them, such that we obtain a scaled measure of institutional development ranging from near-perfect development (left) to grave voids (right). The vertical axis shows the country-specific mean effect sizes we retrieved (Table 3), ranging from substantial affiliate underperformance (bottom) to outperformance (top). The figure also portrays a best-fitting line, showing the general tendencies flowing from the empirical observations, obtained by regressing country-specific mean effect sizes on the first, second, third, and fourth power terms of these countries' institutional development scores. It shows that the institutional voids thesis as it is conventionally stated is only applicable to the nations in the right-upper quadrant (e.g., Brazil, Mexico, and Turkey), where group membership compensates for missing institutions, and the left-lower quadrant (e.g., Belgium, France, and Japan), where affiliates suffer from the conglomerate discount that is commonly observed in developed nations (Khanna $\&$ Palepu, 1997). However, the nations in the remaining two quadrants present some enigmatic questions for institutional voids theorists. Why do BG members do so well relative to unaffiliated firms in contexts with generally well-functioning institutions, like Malaysia, Singapore, and Sweden? And why do they do so unexpectedly poorly in contexts with severe voids, like Nigeria, Pakistan, and Peru? Additional studies are needed to explore why these outliers are so poorly explained by extant institutional voids theory, and to reveal which institutional variables are responsible for their counter-theorized positioning. 


\section{Strategic Choices and Affiliate Performance}

Given the mixed and contingent findings of empirical research on the affiliation-performance link (cf. Khanna \& Rivkin, 2001; Hypotheses1a and 1b), it is surprising that little prior research has examined the influence on this relationship of affiliate-level strategic processes. As noted above, only a few studies have explored how affiliation affects the strategic choices that firms make (e.g. Kim et al., 2004), and no prior work has explicitly evaluated the extent to which such choices mediate the focal relationship. On this point, our findings indicate that greater financial leverage and more diversified product market strategies are pathways associated with lower performance among BG affiliates. As both high levels of leverage and diversification are suggestive of pyramiding and tunneling behavior (cf. Morck \& Yeung, 2003; Mitton, 2002), which results in the inefficient allocation of resources (Scharfstein \& Stein, 2000), our findings are supportive of agency-theoretic perspectives on BGs, at least for affiliates that are on the high end of the leverage and diversification distributions. On the other hand, the application of other theoretical perspectives, such as the RBV (cf. Guillén, 2000) and the institutional voids thesis (cf. Khanna \& Palepu, 2000b), may be necessary to explain affiliation-strategy-performance dynamics among affiliates with moderate to low leverage and diversification levels.

More generally, our findings are suggestive of an important role played by affiliate-level strategic choice in the affiliation-performance link. However, due to the scarcity of strategy variables in the body of primary empirical BG studies, we have been unable to evaluate a more comprehensive set of potential strategy mediators. We view this gap in the body of empirical research as an area of great opportunity for BG scholars. Our leverage and diversification findings provide evidence that certain strategic choices represent pathways through which BG affiliation can harm firm performance. On the other hand, given the evidence that many firms 
benefit from BG affiliation, there should also be other strategic choice pathways which lead to improved performance levels. Accordingly, we call for future research directed towards identifying those specific types of strategies and competence-building activities associated with superior performance among BG affiliates and reason that frameworks and hypotheses drawn from multiple theoretical perspectives represent a logical point of departure for such inquiries.

\section{Group-Level Size Effects: Scale and Scope Both Matter (Differently)}

Our results on the effects of BG size on group-level performance highlight a salient distinction between the related effects of group scale (Hypothesis 4a) and scope (Hypothesis 4b). In this regard, we find that scope mediates the relationship between group-level scale and performance. More specifically, we find that while the direct effect of scale is strongly positive, scale also tends to increase the operational scope of BGs and that such scope actually counteracts some of the performance-enhancing benefits of scale.

In terms of their relevance to alternative theoretical accounts of the size-performance relationship, these findings support views that size affords performance-enhancing benefits related to economies of scale in central management functions (e.g. Amsden \& Hikino, 1994), reputation benefits (e.g. Morck et al., 2005), and the accumulation of market and political power (e.g. Claessens et al. 2000; Khanna \& Yafeh, 2007). On the other hand, we find no benefits associated with scope, such as those suggested by Khanna and Palepu (1997), Chang and Hong (2000), and others. On the contrary, our results support the findings of Hoskisson, Johnson, Tihanyi and White (2005), who highlight the bureaucratic and other costs of managing widely diversified BGs. Thus, while some researchers (e.g. Khanna \& Palepu, 1997) have argued that greater scope benefits BGs as it allows them to fill institutional voids in emerging economies, 
our findings indicate that the capacity to fill such voids through increased scope is not without concomitant costs (cf. Hoskisson et al., 2005). Viewed in this light, the evident scope of many BGs is better described as a cost of doing business in their institutional contexts, rather than as a source of competitive advantage in its own right.

More generally, our findings concerning the contrasting effects of scale and scope suggest that the relationship between group size and performance is complex. That is, rather than being singular in nature, size consists of multiple contrasting effects. Like other findings reported earlier, these results point to the need for researchers, practitioners and policy makers to adopt theories and methodologies which allow them to make sufficiently fine-grained distinctions to capture the complex associations that underlie BG performance characteristics. In this respect, our findings highlight the need for BG researchers to distinguish between the effects of scale and scope both conceptually and empirically. Future research exploring how BG executives manage the complex trade-offs between scale benefits and scope costs and the effects such choices have on their group's competence building and developmental trajectories can yield important new insights regarding the performance characteristics of this important organizational form.

\section{Limitations}

While the various meta-analytical techniques we employed have allowed us to address several previously untested research questions, our study also has two limitations that can only be remedied by means of future primary BG studies. A first limitation is that while we have been able to identify mediating roles for variables like diversification and leverage at both the affiliate and group-levels of analysis, data limitations prevented us from exploring any cross-level interactions involving these variables. Future primary studies are needed, for example, to test 
whether group-level diversification leads to more focus amongst affiliates due to the intent of avoiding competition between affiliates (Gerlach, 1992), or to more affiliate-level diversification due to pyramiding and tunneling behavior (Morck \& Yeung, 2003).

A second limitation of our study design is that meta-analyses do not allow for modeling the influence of time, except in a crude way as a moderator of the focal effect (Coombs et al., 2010) as we have done in our MARA analyses. Additional primary longitudinal studies are therefore needed to capture more nuanced time-dependent performance effects of BG affiliation. For instance, several authors have suggested the hypothesis that the benefits of affiliation decrease over time, as the gradual filling of institutional voids by BGs creates positive externalities which erode the originating benefits of affiliation (Carney, Shapiro, \& Tang, 2009)

\section{Conclusion}

BGs come in many shapes and sizes and their heterogeneity across time and place defies any simple explanation. So what should one conclude? On the evidence assembled in this paper, we conclude that highly polarized characterizations of BGs as either heroic paragons or as villainous robber barons are unwarranted and unproductive. Historical accounts tell us that their emergence and early establishment often occurred under very difficult institutional conditions and that they played a pivotal role in the early stages of many a country or region's economic development (Carney \& Gedajlovic, 2002; Gerlach, 1992; Keister, 1998). These descriptions indicate that BGs are complex social and economic phenomena serving diverse purposes (Cuervo-Cazurra, 2006; Yiu et al., 2007). As a result, BGs are likely to have multiple, conflicting, and complementary effects on their host societies and the firms that affiliate with them. We should then eschew mono-theoretical accounts which characterize BGs in singular terms, such as an internal capital 
market, an extraction device for wealthy families, or a generalized response to chronic institutional failure, since they will likely divert attention away from their evident structural and strategic complexity and the kinds of performance they can attain. More productive in our view is research that employs insights from multiple theoretical streams and is attuned theoretically and methodologically to the complex tensions embodied in BGs. Thus, the development of appropriately nuanced theories and methodologies is both the challenge and opportunity for future research on this important and multifaceted organizational form. 


\section{FIGURE 1}

\section{Relationship between Institutional Voids and Affiliate Performance ${ }^{a}$}

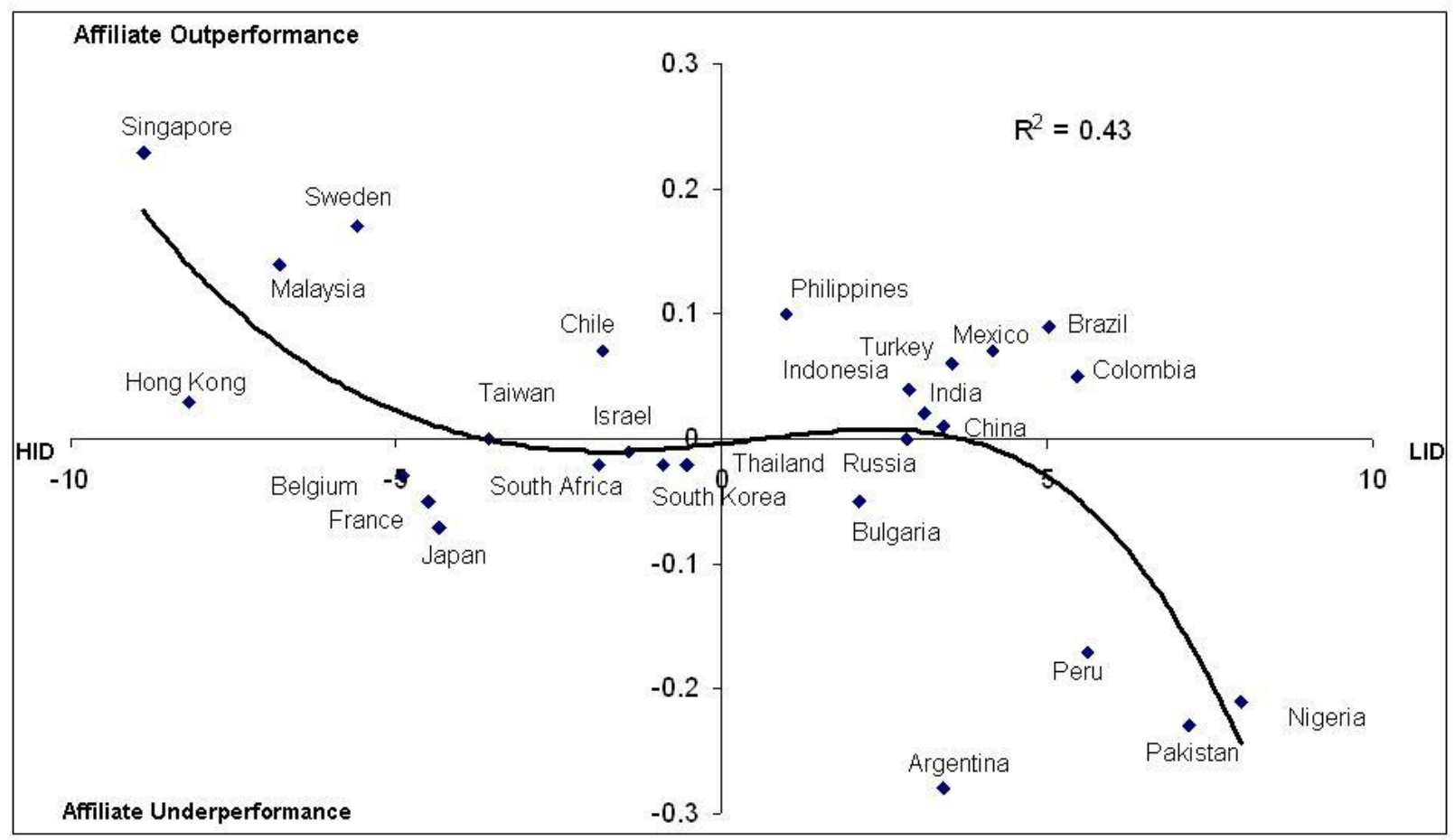

${ }^{\mathrm{a}} \mathrm{HID}=$ high institutional development LID = low institutional development. 
TABLE 1

Firm-Level Correlation-Based HOMA Results ${ }^{\text {a,b }}$

\begin{tabular}{lccccccc}
\hline \multicolumn{1}{c}{ Predictor } & K & $\boldsymbol{N}$ & Mean & $\mathbf{S D}_{\boldsymbol{\rho}}$ & $\mathbf{C I ~ 9 5 \%}$ & $\mathbf{Q ~ t e s t ~}^{\mathbf{I}}$ \\
\hline $\begin{array}{l}\text { Business group affiliation to firm } \\
\text { performance }\end{array}$ & 284 & 831,807 & $\mathbf{- 0 . 0 2 *}$ & 0.01 & $-0.04 /-0.01$ & $5,805.29(0.00)$ & 0.95 \\
$\quad$ & & & & & & & \\
$\quad \begin{array}{l}\text { Accounting measures } \\
\text { Market measures }\end{array}$ & 201 & 672,765 & $\mathbf{- 0 . 0 3 *}$ & 0.01 & $-0.04 /-0.02$ & $4,687.64(0.00)$ & 0.96 \\
& & 159,042 & -0.01 & 0.01 & $-0.03 / 0.01$ & $954.16(0.00)$ & 0.48 \\
\hline
\end{tabular}

${ }^{\text {a }} k=$ number of effect sizes; $N=$ total sample size; mean $\rho=$ estimate of population correlation; $\mathrm{SD}_{\rho}=$ standard deviation of mean $\rho ; \mathrm{CI}_{\text {mean } \rho} 95 \%=95$ percent confidence interval for mean $\rho ; Q=$ Cochran's homogeneity test statistic; $p=$ probability of $Q ; I^{2}=$ scale-free index of heterogeneity.

${ }^{\mathrm{b}}$ Mean effect sizes marked with an asterix $(*)$ are statistically significant $(p<.05)$. 
TABLE 2

\section{Firm-Level Partial Correlation-Based HOMA Results ${ }^{\mathrm{a}, \mathrm{b}}$}

\begin{tabular}{lccccccc}
\hline \multicolumn{1}{c}{ Predictor } & K & $\boldsymbol{N}$ & Mean & $\mathbf{S D}_{\mathbf{\rho}}$ & $\mathbf{C I} \mathbf{9 5 \%}$ & $\mathbf{Q}_{\text {test }}$ & $\boldsymbol{I}^{\mathbf{2}}$ \\
\hline $\begin{array}{l}\text { Business group affiliation to firm } \\
\text { performance }\end{array}$ & 50 & 52,146 & $\mathbf{- 0 . 0 2 *}$ & 0.01 & $-0.04 /-0.00$ & $252.36(0.00)$ & 0.80 \\
$\quad$ & 27 & 24,143 & -0.02 & 0.02 & $-0.05 / 0.01$ & $126.24(0.00)$ & 0.79 \\
$\quad \begin{array}{l}\text { Accounting measures } \\
\text { Market measures }\end{array}$ & 23 & 28,003 & -0.01 & 0.01 & $-0.04 / 0.02$ & $106.38(0.00)$ & 0.78
\end{tabular}

${ }^{\mathrm{a}} k=$ number of effect sizes; $N=$ total sample size; mean $\rho=$ estimate of population correlation; $\mathrm{SD}_{\rho}=$ standard deviation of mean $\rho ; \mathrm{CI}_{\text {mean } \rho} 95 \%=95$ percent confidence interval for mean $\rho ; Q=$ Cochran's homogeneity test statistic; $p=$ probability of $Q ; I^{2}=$ scale-free index of heterogeneity.

${ }^{\mathrm{b}}$ Mean effect sizes marked with an asterix $(*)$ are statistically significant $(p<.05)$. 
TABLE 3

Country-Specific Correlation-Based HOMA Results ${ }^{\mathrm{a}}$

\begin{tabular}{|c|c|c|c|c|c|c|c|}
\hline Country & \% of BGs aff. & $\mathbf{K}$ & $N$ & Mean & $\mathbf{S D}_{\rho}$ & CI $95 \%$ & Q test \\
\hline Argentina & 0.51 & 1 & 129 & -0.28 & & & \\
\hline Belgium & 0.09 & 4 & 20,033 & -0.03 & 0.03 & $-0.09 / 0.03$ & $59.48(0.00)$ \\
\hline Brazil & 0.48 & 1 & 629 & 0.08 & & & \\
\hline Bulgaria & 0.13 & 1 & 114 & -0.05 & & & \\
\hline Chile & 0.47 & 10 & 9,633 & $0.07 *$ & 0.03 & $0.02 / 0.12$ & $45.79(0.00)$ \\
\hline China & 0.66 & 14 & 8,402 & 0.01 & 0.03 & $-0.03 / 0.07$ & $76.01(0.00)$ \\
\hline Colombia & 0.50 & 3 & 1,238 & $0.05^{*}$ & 0.02 & $0.00 / 0.09$ & $1.67(0.43)$ \\
\hline France & 0.38 & 2 & 3,041 & $-0.05^{*}$ & 0.02 & $-0.09 /-0.01$ & $1.16(0.28)$ \\
\hline Hong Kong & 0.20 & 9 & 14,488 & $0.03 *$ & 0.01 & $0.01 / 0.05$ & $12.05(0.15)$ \\
\hline India & 0.43 & 21 & 89,380 & 0.02 & 0.02 & $-0.01 / 0.06$ & $434.19(0.00)$ \\
\hline Indonesia & 0.29 & 3 & 3,674 & $0.04 *$ & 0.02 & $0.00 / 0.08$ & $2.63(0.26)$ \\
\hline Israel & 0.33 & 1 & 86 & -0.01 & & & \\
\hline Japan & 0.41 & 87 & 402,257 & $-0.07^{*}$ & 0.01 & $-0.09 /-0.06$ & $1,548.03(0.00)$ \\
\hline Malaysia & 0.43 & 1 & 121 & 0.14 & & & \\
\hline Mexico & 0.32 & 1 & 344 & 0.06 & & & \\
\hline Nigeria & & 2 & 186 & $-0.21 *$ & 0.07 & $-0.36 /-0.07$ & $0.00(0.99)$ \\
\hline Pakistan & 0.52 & 3 & 498 & $-0.23 *$ & 0.04 & $-0.32 /-0.14$ & $0.41(0.81)$ \\
\hline Peru & 0.26 & 1 & 99 & -0.17 & & & \\
\hline Philippines & 0.37 & 4 & 624 & 0.10 & 0.06 & $-0.01 / 0.23$ & $6.38(0.09)$ \\
\hline Russia & 0.29 & 9 & 1,409 & -0.00 & 0.04 & $-0.09 / 0.08$ & $11.08(0.20)$ \\
\hline Singapore & 0.69 & 1 & 71 & 0.23 & & & \\
\hline South Africa & 0.49 & 1 & 1,071 & -0.02 & & & \\
\hline South Korea & 0.19 & 56 & 240,115 & $-0.02 *$ & 0.01 & $-0.05 /-0.00$ & $1,392.11(0.00)$ \\
\hline Sweden & & 4 & 296 & $0.17 *$ & 0.06 & $0.05 / 0.28$ & $1.53(0.67)$ \\
\hline Taiwan & 0.48 & 15 & 13,599 & -0.00 & 0.03 & $-0.06 / 0.06$ & $152.67(0.00)$ \\
\hline Thailand & 0.60 & 3 & 1,755 & -0.02 & 0.03 & $-0.08 / 0.03$ & $2.26(0.32)$ \\
\hline Turkey & 0.55 & 11 & 2,259 & 0.06* & 0.02 & $0.02 / 0.10$ & $8.68(0.56)$ \\
\hline
\end{tabular}

${ }^{\text {a }}$ Mean effect sizes marked with an asterix $(*)$ are statistically significant $(p<.05)$. 
TABLE 4

Results of Mixed Effects WLS Regression ${ }^{a}$

\begin{tabular}{|c|c|c|c|}
\hline Variable & $\begin{array}{l}\text { Model } \\
\text { (1) }\end{array}$ & $\begin{array}{l}\text { Model } \\
\text { (2) }\end{array}$ & $\begin{array}{c}\text { Model } \\
\text { (3) }\end{array}$ \\
\hline Constant & $-0.03(0.01)^{* * *}$ & $-0.03(0.02)^{*}$ & $-0.04(0.02) *$ \\
\hline
\end{tabular}

\section{Financial infrastructure}

Stock market capitalization

Debt availability

\section{Legal institutions}

Rule of law

Anti-self dealing index

Enforcing contracts

\section{Labor market institutions}

General education level

Business school count

Quality of business schools

Labor market competiveness

\section{Controls}

Published study

Cross-sectional design

Median year sampling window

Journal impact factor

Physical infrastructure

Japan dummy ${ }^{\mathrm{b}}$

Same data control ${ }^{\mathrm{b}}$

$R^{2}$

K

$\mathrm{Q}_{\text {Model }}(p)$

$\mathrm{Q}_{\text {Residual }}(p)$

V

$z$-test
$0.03(0.01)^{*}$
$-0.06(0.02) * * *$

$-0.01(0.00)^{* *}$

$0.06(0.03)^{*}$

$-0.13(0.10)$

$0.00(0.00)$
$-0.02(0.01)^{* * *}$

$-0.02(0.01) * * *$

$-0.02(0.01)^{*}$

$0.04(0.04)$

\begin{tabular}{|c|c|}
\hline$-0.01(0.01)$ & $-0.01(0.01)$ \\
\hline $0.02(0.01)^{*}$ & $0.01(0.01)$ \\
\hline$-0.00(0.00)$ & $-0.003(0.00)$ \\
\hline \multirow[t]{3}{*}{$-0.01(0.00)^{*}$} & $-0.01(0.00)^{* * *}$ \\
\hline & $0.06(0.05)$ \\
\hline & $-0.10(0.03) * * *$ \\
\hline Yes & No \\
\hline 0.35 & 0.28 \\
\hline 284 & 263 \\
\hline $131.36(0.00)$ & $103.46(0.00)$ \\
\hline $243.21(0.56)$ & $264.34(0.21)$ \\
\hline 0.005 & 0.00434 \\
\hline
\end{tabular}

${ }^{a}$ Unstandardized regression coefficients are presented for study moderators and substantive moderators with standard errors in parentheses. $k$ is the total number of effect sizes; $Q$ is the homogeneity statistic with its probability in parentheses; $v$ is the random effects variance component.

${ }^{\mathrm{b}}$ These control variables could not be included in Model 2 because of collinearity issues.

$$
\begin{aligned}
& * \mathrm{p}<.1 \\
& * * \mathrm{p}<.05 \\
& * * * \mathrm{p}<.01
\end{aligned}
$$


TABLE 5

Firm-Level Meta-Analytic Correlation Matrix ${ }^{a}$

\begin{tabular}{|c|c|c|c|c|c|c|c|c|c|}
\hline Variable & 1 & 2 & 3 & 4 & 5 & 6 & 7 & 8 & 9 \\
\hline 1.Business group affiliation & & $13,914(6)$ & $754,005(164)$ & $61,473(44)$ & $79,801(30)$ & $309,545(78)$ & $54,380(30)$ & $173,171(39)$ & $831,807(284)$ \\
\hline 2. Firm age & $-0.00(0.02)$ & & $9,058(4)$ & $2,127(2)$ & $6,073(2)$ & $7,044(3)$ & $1,314(1)$ & $13,101(5)$ & $4,658(3)$ \\
\hline 3. Firm size & $0.26(0.02)$ & $0.09(0.11)$ & & $14,835(15)$ & $81,534(30)$ & $167,529(51)$ & $38,012(15)$ & $67,308(31)$ & $247,693(118)$ \\
\hline 4.Diversification & $0.09(0.01)$ & $-0.13(0.20)$ & $0.13(0.06)$ & & $609(4)$ & $6,792(5)$ & $2,121(4)$ & $7,355(4)$ & $20,317(14)$ \\
\hline 5. Internationalization & $-0.01(0.02)$ & $0.06(0.05)$ & $0.29(0.06)$ & $-0.09(0.06)$ & & $56,956(7)$ & $5,655(5)$ & $29,310(18)$ & $67,080(19)$ \\
\hline 6. Leverage & $0.06(0.01)$ & $0.04(0.02)$ & $0.07(0.01)$ & $0.00(0.01)$ & $-0.02(0.02)$ & & $18,828(13)$ & $67,466(15)$ & $192,874(65)$ \\
\hline 7. Risk & $-0.01(0.03)$ & -0.03 & $-0.19(0.05)$ & $-0.04(0.02)$ & $0.10(0.02)$ & $0.18(0.03)$ & & $10,562(5)$ & $49,860(21)$ \\
\hline 8. R\&D & $0.04(0.01)$ & $-0.01(0.03)$ & $0.14(0.02)$ & $0.03(0.03)$ & $0.17(0.03)$ & $-0.00(0.02)$ & $0.05(0.05)$ & & $57,505(23)$ \\
\hline 9. Performance & $-0.02(0.01)$ & $0.05(0.06)$ & $0.07(0.01)$ & $-0.04(0.02)$ & $0.01(0.02)$ & $-0.14(0.02)$ & $-0.14(0.04)$ & $0.05(0.02)$ & \\
\hline
\end{tabular}

${ }^{a}$ Cells below the diagonal contain mean correlations (mean $\rho$ ) and standard deviations (s.d. $\rho$ ). Cells above the diagonal contain the total number of observations $(N)$ and number of samples $(k)$. Bold font indicates a significant $\chi^{2}$ test, suggesting the presence of moderator variables. 
TABLE 6

\section{Firm-Level MASEM Results ${ }^{\mathrm{a}}$}

\begin{tabular}{lcccc}
\hline \multicolumn{1}{c}{ Predictors } & Diversification & Internationalization & Leverage & Performance \\
\hline Business group affiliation & $\mathbf{0 . 0 6}(\mathbf{4 . 7 0})$ & $\mathbf{- 0 . 0 9}(\mathbf{- 7 . 7 3})$ & $\mathbf{0 . 0 5}(\mathbf{3 . 7 2})$ & $-0.01(-1.06)$ \\
Firm size & $\mathbf{0 . 1 3}(\mathbf{1 0 . 5 5})$ & $\mathbf{0 . 3 1}(\mathbf{2 6 . 3 5})$ & $\mathbf{0 . 0 5}(\mathbf{4 . 4 6})$ & \\
Firm age & $\mathbf{- 0 . 1 4 ( - 1 2 . 0 8 )}$ & $\mathbf{0 . 0 3}(\mathbf{2 . 8 1})$ & $\mathbf{0 . 0 4}(\mathbf{2 . 9 4})$ & \\
& & & $\mathbf{- 0 . 1 2}(\mathbf{- 1 0 . 6 2})$ \\
Risk & & & & $\mathbf{0 . 0 6}(\mathbf{4 . 8 7})$ \\
R\&D & & & $\mathbf{- 0 . 0 5}(\mathbf{- 3 . 8 4})$ \\
Diversification & & & $0.01(0.53)$ \\
Internationalization & & & $\mathbf{- 0 . 1 2}(\mathbf{- 9 . 9 8})$ \\
Leverage & & & \\
& & & \\
Harmonic mean $N$ & 7,065 & & & \\
$\mathrm{X}^{2}$ & 760.09 & & \\
$G F I$ & 0.98 & & \\
$R M S R$ & 0.098 & & & \\
\hline
\end{tabular}

${ }^{\text {a }}$ Significant relationships $(p<.05)$ are printed in bold; $t$-values are given in parentheses. 
TABLE 7

Group-Level Meta-Analytic Correlation Matrix ${ }^{\text {a }}$

\begin{tabular}{lcccccc}
\hline \multicolumn{1}{c}{ Variable } & 1 & 2 & 3 & 4 & 5 & 6 \\
\hline 1. Business group scale & & $23,436(22)$ & $27,124(3)$ & $42,817(18)$ & $23,064(23)$ & $73,326(71)$ \\
2. Business group scope & $\mathbf{0 . 4 7}(\mathbf{0 . 0 5})$ & & $31,206(7)$ & $33,029(16)$ & $5,672(24)$ & $38,495(77)$ \\
3. R\&D & $\mathbf{0 . 2 5}(\mathbf{0 . 0 6})$ & $\mathbf{0 . 0 4}(\mathbf{0 . 0 4})$ & & $52,200(6)$ & $3,086(1)$ & $37,627(7)$ \\
4. Leverage & $\mathbf{- 0 . 0 7 ( 0 . 0 2 )}$ & $\mathbf{0 . 0 1}(\mathbf{0 . 0 2})$ & $\mathbf{- 0 . 0 3 ( \mathbf { 0 . 0 1 } )}$ & & $12,366(9)$ & $62,646(29)$ \\
5. Risk & $\mathbf{- 0 . 1 2 ( 0 . 0 2 )}$ & $\mathbf{- 0 . 0 4}(\mathbf{0 . 0 1})$ & -0.04 & $\mathbf{0 . 2 5}(\mathbf{0 . 0 4})$ & & $38,266(44)$ \\
6. Performance & $\mathbf{0 . 0 7}(\mathbf{0 . 0 2})$ & $\mathbf{- 0 . 0 8 ( \mathbf { 0 . 0 3 } )}$ & $\mathbf{0 . 0 5}(\mathbf{0 . 0 2})$ & $\mathbf{- 0 . 1 9}(\mathbf{0 . 0 3})$ & $\mathbf{- 0 . 2 6 ( \mathbf { 0 . 0 3 } )}$ & \\
\hline
\end{tabular}

${ }^{a}$ Cells below the diagonal contain mean correlations (mean ${ }_{\rho}$ ) and standard deviations (s.d. $\rho$ ). Cells above the diagonal contain the total number of observations $(N)$ and number of samples $(k)$. Bold font indicates a significant $\chi^{2}$ test, suggesting the presence of moderator variables. 
TABLE 8

\section{Group-Level MASEM Results ${ }^{\mathrm{a}}$}

\begin{tabular}{|c|c|c|}
\hline Predictors & Business group scope & Performance \\
\hline Business group scale & $0.47(68.08)$ & $0.09(10.53)$ \\
\hline Business group scope & & $-0.13(-15.62)$ \\
\hline Leverage & & $-0.13(-16.45)$ \\
\hline$R \& D$ & & $0.02(2.58)$ \\
\hline Risk & & $-0.22(-28.79)$ \\
\hline Harmonic mean $N$ & 16,353 & \\
\hline $\mathrm{X}^{2}$ & $172.10(0.00)$ & \\
\hline$G F I$ & 0.99 & \\
\hline$R M S R$ & 0.02 & \\
\hline
\end{tabular}

${ }^{\text {a }}$ Significant relationships $(p<.05)$ are printed in bold; $t$-values are given in parentheses. 


\section{REFERENCES}

Almeida, H., \& Wolfenzon, D. 2006. Should business groups be dismantled? The equilibrium costs of efficient internal capital markets. Journal of Financial Economics, 79: 99-144.

Amsden, A. H. \& Hikino, T. 1994. Project execution capability, organizational know-how and conglomerate corporate growth in late industrialization. Industrial and Corporate Change, 3: $111-147$.

Bae, K-H., Kang, J-K., \& Kim, J-M. 2002. Tunneling or value added? Evidence from mergers by Korean business group. Journal of Finance, 57: 2695-2740.

Baron, R. M., \& Kenny, D. A. 1986. The moderator-mediator variable distinction in social psychological research: Conceptual, strategic, and statistical considerations. Journal of Personality and Social Psychology, 51: 1173-1182.

Berglöf, E., \& Perotti, E. 1994. The governance structure of the Japanese financial keiretsu. Journal of Financial Economics, 36: 259-284.

Bertrand, M., Mehta, P., \& Mullainathan, S. 2002. Ferreting out tunneling: An application to Indian business groups. Quarterly Journal of Economics, 117: 121-48.

Bijmolt, T. H. A., \& Pieters, R. G. M. 2001. Meta-analysis in marketing when studies contain multiple measurements. Marketing Letters, 12: 157-169.

Carney, M. 2004. The institutions of industrial restructuring in Southeast Asia. Asia Pacific Journal of Management, 21: 171-188.

Carney, M. 2008. The many futures of Asian business groups. Asia Pacific Journal of Management, 25: 595-613.

Carney, M., \& Gedajlovic, E. 2002. The co-evolution of institutional environments and organizational strategies: The rise of family business groups in the ASEAN region. Organization Studies, 23: 1-31. 
Carney, M., Shapiro, D., \& Tang, Y. 2009. Business group performance in China: Ownership and temporal considerations. Management and Organization Review, 5: 167-193.

Chang, S. J. 2003. Ownership structure, expropriation, and performance of group-affiliated companies in Korea. Academy of Management Journal, 46: 238-254.

Chang, S. J., \& Choi, U. 1988. Strategy structure and performance of Korean business groups. Journal of Industrial Economics, 37: 141-158.

Chang, S. J., \& Hong, J. 2000. Economic performance of group-affiliated companies in Korea: Intragroup resource sharing and internal business transactions. Academy of Management Journal, 43: 429-448.

Chang, S. J. \& Hong, J. 2002. How much does the business group matter in Korea? Strategic Management Journal, 23: 265-274.

Cheung, M. W-L., \& Chan, W. 2005. Meta-analytic structural equation modeling: A two-stage approach. Psychological Methods, 10: 40-64.

Claessens, S., Djankov, S., \& Lang, L. H. P. 2000a. East Asian corporations: Heroes or villains? World Bank discussion paper 409.

Claessens, S., Djankov, S., \& Lang, L. H. P. 2000b. The separation of ownership and control in East Asian corporations. Journal of Financial Economics, 58: 81-112.

Claessens, S., Fan, J. P. H., \& Lang, L. H. P. 2006. The benefits and costs of group affiliation: Evidence from East Asia. Emerging Markets Review, 7: 1-26.

Cohen, J. 1977. Statistical power analysis for the behavioral sciences. Revised ed. New York: Academic Press.

Colpan, A. M. 2006. Dynamic effects of product diversity, international scope and keiretsu membership on the performance of Japan's textile firms in the 1990s. Asian Business \& Management, 5: 419-445.

Combs, J. G., Ketchen, J. G. J., Crook, T. R., \& Roth, P. L. 2010. Assessing cumulative evidence 
within 'macro' research: Why meta-analysis should be preferred over vote counting. Journal of Management Studies (In press).

Cuervo-Cazurra, A. 2006. Business groups and their types. Asia Pacific Journal of Management, 23: 419-439.

Davis, G. F., Diekman, K., \& Tinsley, C. H. 1994. The decline and fall of the conglomerate firm in the 1980s: The deinstitutionalization of an organizational form. American Sociological Review, 59: 547-570.

Dieleman, M. \& Sachs, W. M. 2008. Coevolution of institutions and corporations in emerging economies: How the Salim group morphed into an institution of Suharto's crony regime. Journal of Management Studies, 45: 1274-1300.

Djankov, S., La Porta, R., López-de-Silanes, F., \& Shleifer, A. 2008. The law and economics of self-dealing. Journal of Financial Economics, 88: 430-465.

Doucouliagos, H. \& Ulubaşoğlu, M. A. 2008. Democracy and economic growth: A metaanalysis. American Journal of Political Science, 52: 61-83.

Eden, D. 2002. From the editors: Replication, meta-analysis, scientific progress, and AMJ's publication policy, Academy of Management Journal, 45: 841-846.

Encarnation, D. J. 1989. Dislodging multinationals: India's strategy in comparative perspective. Ithaca and London: Cornell University Press.

Faccio, M., Lang, L. H. P., \& Young, L. 2001. Dividends and expropriation. American Economic Review, 91: $54-78$

Feingold, A. 1992. Good-looking people are not what we think. Psychological Bulletin, 111, 304-341.

Ferris, S. P., Kim, K. A., \& Kitsabunnarat, P. 2003. The costs (and benefits?) of diversified business groups: The case of Korean chaebols. Journal of Banking \& Finance, 27: 251273. 
Fisher, R. A. 1928. Statistical methods for research workers (2nd ed.). London: Oliver \& Boyd.

Fisman, R., \& Khanna, T. 2004. Facilitating development: The role of business groups. World Development, 32: 609-628.

Friedman, E., Johnson, S., \& Mitton, T. 2003. Propping and tunneling. Journal of Comparative Economics, 31: 732-750.

Gedajlovic, E. R., \& Shapiro, D. M. 2002. Ownership and firm profitability in Japan. Academy of Management Journal, 45: 575-585.

Gerlach, M. L. 1992. Alliance capitalism: The social organization of Japanese business. Berkeley, CA: University of California Press.

Geyskens, I., Krishnan, R., Steenkamp, J.-B. E. M., \& Cunha, P. V. 2009. A review and evaluation of meta-analysis practices in management research. Journal of Management, 35: 393-419.

Granovetter, M. 2005. Business groups and social organization. In N. J. Smelser, \& R. Swedberg (Eds.), The handbook of economic sociology 2nd ed.: 429-450. Princeton: Princeton University Press.

Greene, W. H. 2008. Econometric analysis. New Jersey: Pearson Prentice Hall.

Guillén, M. F. 2000. Business groups in emerging economies: A resource based view. Academy of Management Journal, 43: 362-380.

Hedges, L.V. \& Olkin, I. 1985. Statistical methods for meta-analysis. Orlando, FL: Academic Press.

Heugens, P. P. M. A. R., van Essen, M., \& van Oosterhout, J. 2009. Meta-analyzing ownership concentration and firm performance in Asia: Towards a more fine-grained understanding. Asia Pacific Journal of Management, 26: 481-512.

Hoskisson, R. E., Cannella, A. A., Tihanyi, L., \& Faraci, R. 2004. Asset restructuring and business group affiliation in French civil law countries. Strategic Management Journal, 
25: 525-539.

Hoskisson, R. E., Johnson, R. A., Tihanyi, L., \& White, R. 2005. Diversified business groups and corporate refocusing in emerging economies. Journal of Management, 31: 941-965.

Hundley, G., \& Jacobson, C. K. 1998. The effects of the keiretsu on the export performance of Japanese companies: Help or hindrance? Strategic Management Journal, 19: 927-937.

Johnson, S., Boone, P., Breach, A., \& Friedman, E. 2000. Corporate governance in the Asian financial crisis. Journal of Financial Economics, 58: 141-186.

Kaufmann, D., Kraay, A., \& Mastruzzi, M. 2005. Governance matters III: Updated governance indicators for 1996-04. Working Paper, Washington D.C., World Bank.

Keister, L. A. 1998. Engineering growth: Business groups structure and firm performance in China's transition economy. American Journal of Sociology, 104: 404-440.

Keister, L. A. 2000. Chinese business groups: The structure and impact of interfirm relations during economic development. New York: Oxford University Press.

Keister, L. A. 2001. Exchange structures in transition: Lending and trade relations in Chinese business groups. American Sociological Review, 66: 336-360.

Khanna, T., \& Palepu, K. 1997. Why focused strategies may be wrong for emerging markets. Harvard Business Review, 75: 41-51.

Khanna, T. \& Palepu, K. 1999. The right way to restructure conglomerates in emerging markets. Harvard Business Review, 77: 125-134.

Khanna, T., \& Palepu, K. 2000a. The future of business groups in emerging markets: Long run evidence from Chile. Academy of Management Journal, 43: 268-285.

Khanna, T., \& Palepu, K. 2000b. Is group affiliation profitable in emerging markets? An analysis of diversified Indian business groups. Journal of Finance, 55: 867-891.

Khanna, T., \& Rivkin, J. W. 2001. Estimating the performance effects of business groups in emerging markets. Strategic Management Journal, 22: 45-74. 
Khanna, T., \& Yafeh, Y. 2005. Business groups and risk sharing around the world. Journal of Business, 78: 301-340.

Khanna, T., \& Yafeh, Y. 2007. Business groups in emerging markets: Paragons or parasites? Journal of Economic Literature, 45: 331-372.

Kim, H., Hoskisson, R., \& Wan, W. P. 2004. Power dependence, diversification strategy, and performance in keiretsu member firms. Strategic Management Journal, 25: 613-636.

Kock, C. J., \& Guillén, M. F. 2001. Strategy and structure in developing countries: Business groups as an evolutionary response to opportunities for unrelated diversification. Industrial and Corporate Change, 10: 77-113.

Lamin, A. 2006. The effect of business group affiliation on firm market and international strategies. Working paper.

Lee, K., Peng, M. W., \& Lee, K. 2008. From diversification premium to diversification discount during institutional transitions. Journal of World Business, 43: 47-65.

Leff, N. H. 1978. Industrial organization and entrepreneurship in the developing countries: The economic groups. Economic Development and Cultural Change, 26: 661-675.

Lincoln, J., R., \& Gerlach, M., L. 2004. Japan's Network Economy: Structure, Persistence, and Change. Cambridge United Kingdom: Cambridge University press.

Lincoln, J. R., Gerlach, M. L., \& Ahmadjian, C. L. 1996. Keiretsu networks and corporate performance in Japan. American Sociological Review, 61: 67-88.

Lins, K. V., \& Servaes, H. 2002. Is corporate diversification beneficial in emerging markets? Financial Management, 31: 5-31.

Lipsey, M.W., \& Wilson, D. B. 2001. Practical meta-analysis. Thousand Oaks, CA: Sage.

Luo, X., \& Chung, C-N. 2005. Keeping it all in the family: The role of particularistic relationships in business group performance during institutional transition. Administrative Science Quarterly, 50: 404-439. 
Mackie, J. 1992. Changing patterns of big business in Southeast Asia. In R. McVey (Ed.), Southeast Asian Capitalism: 161-190. New York: Cornell University Southeast Asia Program.

MacKinnon, D. P., \& Dwyer, J. H. 1993. Estimating mediated effects in prevention studies. Evaluation Review, 17: 144-158.

Mahmood, I., \& Mitchell, W. 2004. Two faces: Effects of business groups on innovation in emerging economies. Management Science, 50: 1348-1365.

McGuire, J. B., \& Dow, S. 2009. Japanese keiretsu: Past, present, future. Asia Pacific Journal of Management, 26: 333-351.

Merton, R. K. 1968. Social theory and social structure. New York: Free Press.

Mitton, T. 2002. A cross- firm analysis of the impact of corporate governance on the East Asian financial crisis. Journal of Financial Economics. 64: 215-241.

Morck, R., \& Nakamura, M. 1999. Banks and corporate control in Japan. Journal of Finance, 54: 319-341.

Morck, R., Wolfenzon, D., \& Yeung, B. 2005. Corporate governance, economic entrenchment, and growth Journal of Economic Literature, 43: 655-720.

Morck, R., \& Yeung, B. 2003. Agency problems in large family business groups. Entrepreneurship Theory and Practice, 27: 367-383.

Numazaki, I. 1996. The role of personal networks in the making of Taiwan's guanxiqiye (related enterprises) In G. G. Hamilton (Ed.), Asian Business Networks: 71-84. Berlin: Walter de Gruyter.

Perotti, E. C., \& Gelfer, S. 2001. Red barons or robber barons? Governance and investment in Russian financial-industrial groups. European Economic Review, 9: 1601-1617.

Raudenbush, S. W., \& Bryk, A. S. 2002. Hierarchical linear models: Applications and data analysis methods (2nd ed.). Thousand Oaks, CA: Sage. 
Scharfstein, D. S. \& Stein, J. C. 2000. The dark side of internal capital markets: Divisional rentseeking and inefficient investment. Journal of Finance, 55: 2537-2564.

Strachan, H. W. 1976. Family and other business groups in economic development: The case of Nicaragua. New York: Praeger.

Viswesvaran, C., \& Ones, D. S. 1995. Theory testing: Combining psychometric meta analysis and structural equations modeling. Personnel Psychology, 48, 865-885.

Weidenbaum, M., \& Hughes, S. 1996. The bamboo network: How expatriate Chinese entrepreneurs are creating a new economic superpower in Asia. New York: Free Press.

Weinstein, D. E., \& Yafeh, Y. 1998. On the costs of a bank-centered financial system: Evidence from the changing main bank relations in Japan. Journal of Finance, 53: 635-672.

Whited, T. M. 2001. Is it inefficient investment that causes the diversification discount? Journal of Finance, 61: 1667-1691.

Williamson, O. E. 1975. Markets and hierarchies: Analysis and antitrust implications. New York: Free Press.

Wong, G. 1996. Business groups in a dynamic environment: Hong Kong 1976-1986. In G. G. Hamilton (Ed.), Asian business networks: 87-112. Berlin: de Gruyter.

Yiu, D., Lu, Y., Bruton, G. D., \& Hoskisson, R. E. 2007. Business groups: An integrated model to focus future research. Journal of Management Studies, 44: 1551- 1579.

Yoshihara, K. 1988. The rise of Ersatz capitalism in South-East Asia. Oxford: Oxford University Press. 
APPENDIX A:

Studies Included in the Meta-Analysis ${ }^{\mathrm{a}}$

\begin{tabular}{|c|c|c|}
\hline Author & Year & Publication \\
\hline Aburime & 2008 & WP \\
\hline Ananchotikul & 2006 & WP \\
\hline Ang \& Constand & 2002 & JMFM \\
\hline Bae \& Jeong & 2007 & JBFA \\
\hline Baek, Kang \& Park & 2001 & WP \\
\hline Basu, Hwang, Mitsudome \&Weintrop & 2007 & PBFJ \\
\hline Belenzon \& Berkovitz & 2008 & WP \\
\hline Bertrand, Mehta \& Mullainathan & 2002 & QJE \\
\hline Beuselinck \& Deloof & 2006 & WP \\
\hline Black, Jang \& Kim & 2006 & $\mathrm{JCF}$ \\
\hline Black \& Khanna & 2007 & JELS \\
\hline Boubaker & 2007 & MFJ \\
\hline Buysschaert, Deloof, Jegers \& Rommens & 2008 & CGIR \\
\hline Carney, Shapiro \& Tang & 2009 & MOR \\
\hline Chang, Cho \& Sin & 2007 & CGIR \\
\hline Chang \& Shin & 2006 & CGIR \\
\hline Chang & 2003 & AMJ \\
\hline Chang \& Hong & 2000 & AMJ \\
\hline Chang, Chung \& Mahmood & 2006 & OS \\
\hline Cheng \& Firth & 2005 & CGIR \\
\hline Cheng \& Firth & 2006 & MDE \\
\hline Choe \& Roehl & 2007 & LRP \\
\hline Choi, Park \& Yoo & 2005 & WP \\
\hline Choi \& Yoo & 2005 & WP \\
\hline $\mathrm{Chu}$ & 2004 & SBE \\
\hline Chung & 2008 & WP \\
\hline Chung \& Luo & 2008 & OS \\
\hline Chung \& Luo & 2008 & OS \\
\hline Chung & 2006 & APJM \\
\hline Chung, Ho \& Kim & 2004 & JIAAT \\
\hline Claessens, Djankov, Fan, \& Lang & 1999 & WP \\
\hline Claessens, Fan, \& Lang & 2006 & EMR \\
\hline Collin & 2002 & WP \\
\hline Colpan & 2006 & $\mathrm{ABM}$ \\
\hline David, Hitt \& Liang & 2003 & WP \\
\hline Dewaelheyns \& Van Hulle & 2009 & EFM \\
\hline Douthett \& Jung & 2001 & JIFMA \\
\hline Douthett, Jung \& Kwak & 2004 & RQFA \\
\hline Dow \& McGuire & 2004 & WP \\
\hline Dow \& McGuire & 2007 & WP \\
\hline Elango \& Chinmay & 2007 & JIBS \\
\hline Estrin, Poukliakova \& Shapiro & 2009 & JMS \\
\hline Faccio \& Sengupta & 2006 & WP \\
\hline Ferris, Kim \& Kitsabunnarat & 2003 & JBF \\
\hline Ferris, Kumar, \& Sarin & 1995 & PBFJ \\
\hline Filatotchev, Lien \& Piesse & 2005 & APJM \\
\hline Firth, Tam \& Tang & 1999 & OME \\
\hline Fisman \& Khanna & 2004 & WD \\
\hline Flath & 1994 & CEP \\
\hline Gadhoum & 2002 & WP \\
\hline Gadhoum, Gueyié \& Zoubeidi & 2007 & CG \\
\hline Gaur \& Kumar & 2008 & BJM \\
\hline
\end{tabular}




\begin{tabular}{|c|c|c|}
\hline Author & Year & Publication \\
\hline George \& Kabir & 2008 & JBR \\
\hline George, Kabir \& Qian & 2005 & WP \\
\hline George & 2007 & SAJM \\
\hline Ghosh & 2006 & EMFT \\
\hline Ginglinger \& Hamon & 2007 & WP \\
\hline Gohar & 2008 & WP \\
\hline Gonenc \& Aybar & 2006 & CGIR \\
\hline Gonenc, Kan \& Karadagli & 2007 & EMFT \\
\hline Gormley, Johnson \& Rhee & 2008 & WP \\
\hline Gramlich, Limpaphayom \& Rhee & 2004 & JAE \\
\hline Guillén & 2000 & AMJ \\
\hline Guillén & 2002 & AMJ \\
\hline Guillén & 2003 & JIBS \\
\hline Gutierrez \& Pombo & 2007 & WP \\
\hline Habib & 2006 & RAF \\
\hline Hoskisson, Cannella, Tihanyi \& Faraci & 2004 & SMJ \\
\hline Hundley \& Jacobson & 1998 & SMJ \\
\hline Isobe, Makino \& Goerzen & 2006 & APJM \\
\hline Jung, Kim \& Kim & 2007 & WP \\
\hline Kakani & 2001 & WP \\
\hline Kato, Kim, \& Lee & 2007 & PBFJ \\
\hline Keister & 1998 & AJS \\
\hline Khanna \& Palepu & 2000 & AMJ \\
\hline Khanna \& Rivkin & 2001 & SMJ \\
\hline Khanna \& Rivkin & 2006 & OS \\
\hline Kim \& Chizema & 2008 & WP \\
\hline Kim, Jung \& Kim & 2005 & RQFA \\
\hline Kim, Heshmati \& Aoun & 2006 & AEJ \\
\hline Kim \& Kim & 2008 & WP \\
\hline Kim \& Kim & 2008 & WP \\
\hline Kim, Kim, \& Lee & 2008 & OS \\
\hline Kim \& Yi & 2006 & CAR \\
\hline Kim, Lim \& Sung & 2007 & PBFJ \\
\hline Kim, Lyn, Park \& Zychowicz & 2005 & JBFA \\
\hline Kim & 2005 & CG:IR \\
\hline Kim, Park, Ratti \& Shin & 2004 & HJE \\
\hline Kobeissi & 2004 & WP \\
\hline Lamin & 2006 & WP \\
\hline Lee \& Hahn & 2007 & SJE \\
\hline Lee, Peng \& Lee & 2008 & JWB \\
\hline Lee, Park \& Shin & 2009 & JBF \\
\hline Lefort \& Walker & 2005 & WP \\
\hline Lensink, van der Molen \& Gangopadhyay & 2003 & JDS \\
\hline Lichtenberg \& Pushner & 1994 & JWE \\
\hline Lincoln, Gerlach \& Ahmadjian & 1996 & ASR \\
\hline Lu \& Yao & 2006 & APJM \\
\hline Luo \& Chung & 2005 & ASQ \\
\hline Мa, Yao \& Xi & 2006 & APJM \\
\hline Mahmood \& Mitchell & 2004 & MS \\
\hline Majumdar \& Sen & 2006 & $\mathrm{PC}$ \\
\hline Manos, Murinde \& Green & 2007 & JEB \\
\hline Marisetty \& Subrahmanyam & 2010 & JFM \\
\hline
\end{tabular}




\begin{tabular}{|c|c|c|}
\hline Author & Year & Publication \\
\hline Mitton & 2002 & JFE \\
\hline Morck, Nakamura \& Shivdasani & 2000 & JB \\
\hline Mueller, Dietl \& Peev & 2003 & JIIDT \\
\hline Mursitama & 2006 & APJM \\
\hline Nguyen \& Nivoix & 2009 & AFE \\
\hline Pak \& Park & 2004 & MIR \\
\hline Pallathitta & 2005 & DIS \\
\hline Park \& Kim & 2008 & JWB \\
\hline Park, Lee \& Jang & 2004 & WP \\
\hline Peng \& Jiang & 2006 & WP \\
\hline Peng \& Jiang & 2010 & JMS \\
\hline Perotti \& Gelfer & 2001 & EER \\
\hline Piga \& Vivarelli & 2004 & OBES \\
\hline Ramaswamy, Li \& Petitt & 2004 & APJM \\
\hline Rommens, Cuyvers \& Deloof & 2007 & WP \\
\hline Sambharya \& Banerji & 2006 & MIR \\
\hline Selarka & 2005 & EMFT \\
\hline Shumilov \& Volchkova & 2004 & WP \\
\hline Silva, Majluf \& Paredes & 2006 & JBR \\
\hline Singh & 2009 & IBR \\
\hline Singh \& Gaur & 2009 & CG:IR \\
\hline Singh, Nejadmalayeri \& Mathur & 2007 & JBR \\
\hline Sirmon, Arregle, Hitt \& Webb & 2008 & ETP \\
\hline Suetorsak & 2007 & JEF \\
\hline Tabeta \& Rahman & 1999 & APJM \\
\hline Unite, Sullivan, Brookman, Majadillas \& Taningco & 2008 & PBFJ \\
\hline van der Molen \& Lensink & 2004 & WP \\
\hline Volchkova & 2001 & WP \\
\hline Weinstein \& Yafeh & 1995 & JIE \\
\hline White, Hoskisson, Yiu \& Bruton & 2008 & MOR \\
\hline $\mathrm{Xu}$ & 2008 & WP \\
\hline Yamak \& Üsdiken & 2006 & BJM \\
\hline Yiu, Bruton \& Lu & 2005 & JMS \\
\hline Yoo & 2008 & WP \\
\hline Yoshikawa \& Colpan & 2008 & WP \\
\hline Yoshikawa \& Gedajlovic & 2002 & APJM \\
\hline Yu, Lensink \& Van Ees & 2007 & WP \\
\hline
\end{tabular}

a ABM: Asian Business \& Management; AEJ: Asian Economic Journal; AFE: Applied Financial Economics; AJS: American Journal of Sociology; AMJ: Academy of Management Journal; APJM: Asia Pacific Journal of Management; ASQ: Administrative Science Quarterly; ASR: American Sociological Review; BJM: British Journal of Management; CAR: Contemporary Accounting Research; CEP: Contemporary Economic Policy; CG: Corporate Governance; CGIR: Corporate Governance: An International Review; DIS: Dissertation; EER: European Economic Review; EFM: European Financial Management; EMFT: Emerging Markets, Finance and Trade; EMR: European Management Review; ETP: Entrepreneurship Theory \& Practice Journal; HJE: Hitotsubashi Journal of Economics; IBR: International Business Review; JAE: Journal of Accounting and Economics; JB: Journal of Business; JBF: Journal of Banking \& Finance; JBFA: Journal of Business Finance \& Accounting; JBR: Journal of Business Research; JCF: Journal of Corporate Finance; JEB: Journal of Economics and Business; JEF: Journal of Economics and Finance; JELS: Journal of Empirical Legal Studies; JFM: Journal of Financial Markets; JFE: Journal of Financial Economics; JIAAT: Journal of International Accounting, Auditing and Taxation; JIBS: Journal of International Business Studies; JIE: Journal of Industrial Economics; JIFMA: Journal of International 
Financial Management and Accounting; JIIDT: Journal for Institutional Innovation Development and Transition; JMFM: Journal of Multinational Financial Management; JMS: Journal of Management Studies; JWB: Journal of World Business; JWE: Japan and the World Economy; LRP: Long Range Planning; MDE: Managerial and Decision Economics; MFJ: Multinational Finance Journal; MIR: Management International Review; MOR: Management and Organization Review;MS: Management Science; OBES: Oxford Bulletin of Economics and Statistics; OME: Omega; OS: Organization Science; QJE: Quarterly Journal of Economics; PBFJ: Pacific-Basin Finance Journal; PC: Public Choice; RAF: Review of Accounting and Finance; RQFA: Review of Quantitative Finance and Accounting; SAJM: South Asian Journal of Management; SBE: Small Business Economics; SJE: Seoul Journal of Economics; SMJ: Strategic Management Journal; WD: World Development; WP: Working Paper. 


\section{AUTHOR BIOGRAPHIES}

Michael Carney (mcarney@jmsb.concordia.ca) is Concordia University Research Chair in Strategy and Entrepreneurship at the John Molson School of Business, Concordia University. He received his $\mathrm{PhD}$ from Bradford University (UK). His research focuses upon family firms and the interaction of institutional context and corporate structures and strategies.

Eric Gedajlovic (erg@sfu.ca) is a Professor at the Faculty of Business Administration at Simon Fraser University where he holds a joint appointment in the areas of Strategy and Innovation and Entrepreneurship. He received his Ph.D. from Concordia University (Montreal). His research focuses on entrepreneurship, family business and the comparative analysis of business, financial and governance systems and their influence upon the development of firm capabilities, strategic assets and national competitiveness.

Pursey Heugens (pheugens@rsm.nl) is a Professor of Organization Theory at the Rotterdam School of Management, Erasmus University. He received his PhD from the same school. His research interests include institutional, ecological, and bureaucracy approaches to organization, as well as the strategy and governance processes of niched organizational forms like business groups, family firms, and professional service firms.

Marc van Essen (m.essen@uu.nl) is an Assistant Professor of Finance at the Utrecht School of Economics at Utrecht University. He received his Ph.D. from the Rotterdam School of Management, Erasmus University. His research interests include comparative corporate governance, family business, and meta-analytic research methods.

J. (Hans) van Oosterhout (joosterhout@rsm.nl) is a Professor of Corporate Governance and Responsibility at the Rotterdam School of Management, Erasmus University, from which he also received his $\mathrm{PhD}$. His research interests include comparative corporate governance, ownership of enterprise organizations, and the role of corporations in shaping the global rules of the game. 